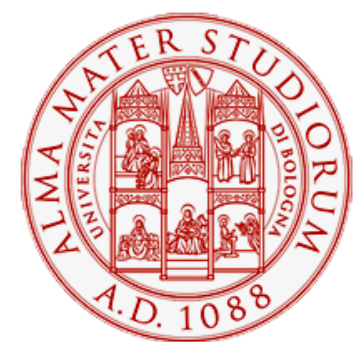

Alma Mater Studiorum - Università di Bologna DEPARTMENT OF ECONOMICS

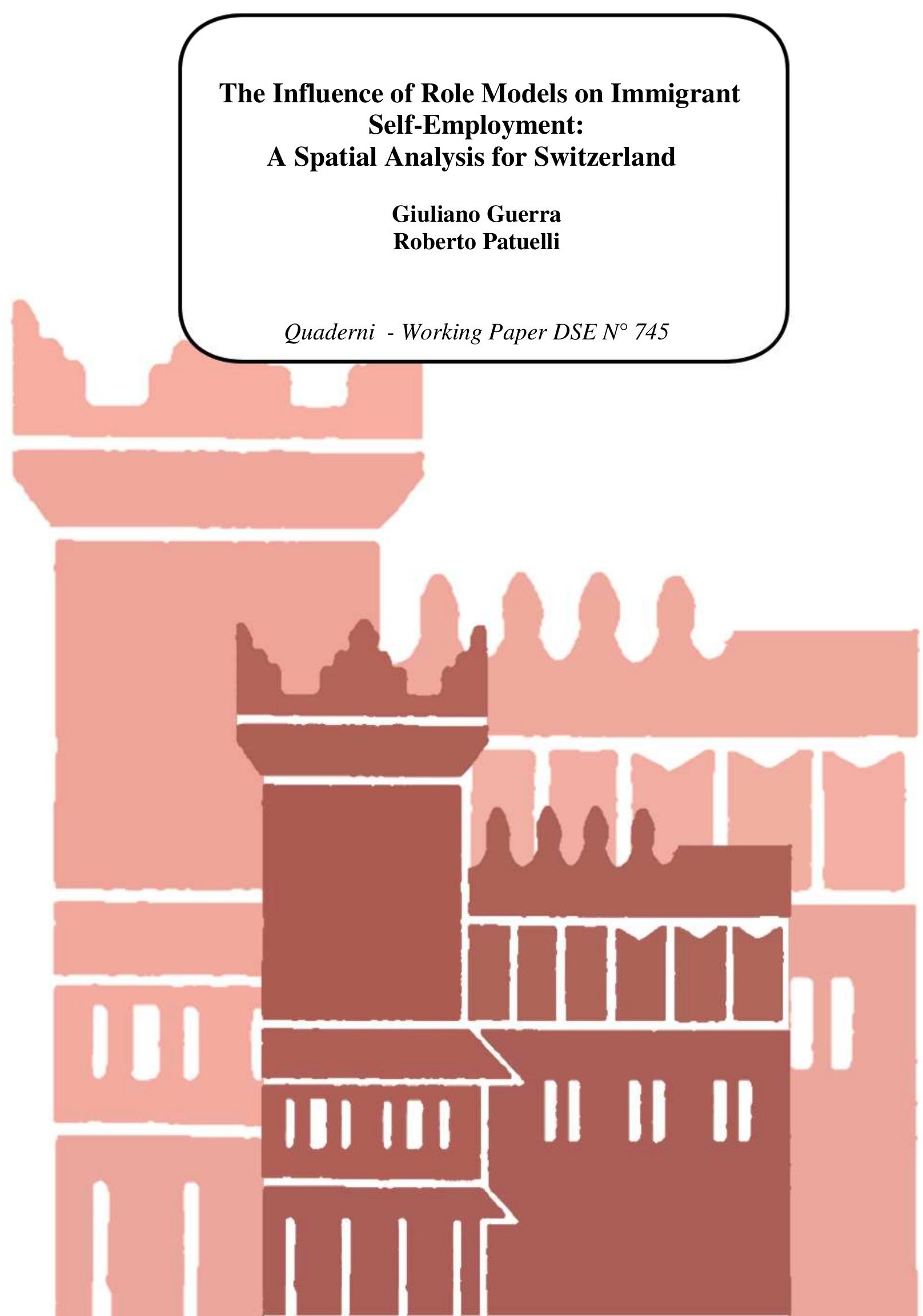




\title{
The Influence of Role Models on Immigrant Self-Employment: A Spatial Analysis for Switzerland
}

\author{
Giuliano Guerra ${ }^{1}$ \\ Roberto Patuelli ${ }^{1,2,3}$
}

${ }^{1}$ Institute for Economic Research (IRE), University of Lugano, Switzerland. E-mails: giuliano.guerra@usi.ch; roberto.patuelli@unibo.it ${ }^{2}$ Department of Economics, Faculty of Economics-Rimini, University of Bologna, Italy

${ }^{3}$ The Rimini Centre for Economic Analysis, Italy

\begin{abstract}
Theoretical and empirical research suggests a connection between the presence of role models and the emergence of entrepreneurs. Existing entrepreneurs may act as role models for self-employment candidates by providing successful examples. By explicitly considering the self-employment rates of the natives, which may influence locally the decisions of immigrants towards entrepreneurship, we develop a simple model that explains immigrant self-employment rates for a sample of 2,490 Swiss municipalities. In addition, we accommodate for the presence of spatial spillovers in the distribution of rates, and test a spatial autoregressive model which takes into account the average self-employment rates of immigrants living in nearby municipalities. Our evidence shows a significant (positive) effect of such spatial network effects, which are characterized by a quick distance decay, suggesting spatial spillovers at the household and social network level. Additionally, we show that local conditions and immigrant pool characteristics differ, with respect to self-employment choices, when examining separately urban and rural contexts.
\end{abstract}

JEL codes: C21, J24, J61, O15, R23

Keywords: immigrants, self-employment, role models, Switzerland, spatial lag 


\section{Introduction}

Since the late 1970s, somewhat in contrast with the global trend of increasing firm size, many countries have witnessed the emergence of a blooming small- and medium-sized enterprise sector that consistently and increasingly influenced labour market outcomes (in terms of job creation). Moreover, the evolution of the small business sector has led to promising changes in modern economies, playing an important role in technological change and in the growth and evolution of industries (Acs and Preston 1997).

At the same time, western societies experienced major demographic transformations. Past and current immigration trends led to cities and countries experiencing increasing flows of people with a different ethnic background, creating the conditions for the surge of new business activities in specific and separate ethnic segments of the population. Initially, ethnic enterprises were serving predominantly the needs of the ethnic minority, but increasingly they began to expand their market share to cover other groups' and even the natives' demand for final goods and services. Later on, immigrant businesses were found to be influent in direct and induced demand for factors of production, housing and land, while they were fostering technological change, scale and agglomeration economies, and many other economic and demographic changes (for example, in labour market structure, labour force participation, unemployment, internal migration, externalities and fertility patterns; Greenwood 1994). In this framework, ethnic enterprises have become popular (Masurel et al. 2002). Thus, cultural and ethnic diversity eventually represents an opportunity for immigrants that can be realized through entering the self-employment sector.

The literature on immigrant entrepreneurial activity mostly focuses on the individual characteristics of ethnic entrepreneurs, whereas the underlying regional and structural conditions are investigated only to explain individual heterogeneity and unexplained common factors. For instance, the only way in which previous studies have considered space is through the inclusion of regional dummies (fixed effects), explaining regional differences by the differences in industrial and occupational composition of local labour markets, the unemployment level (Clark and Drinkwater 1998) or by the concentration of particular groups in some areas (ethnic enclaves; Borjas 1986).

The relevance of spatial dependence in self-employment rates has been largely ignored in the literature. Spatial dependence in entrepreneurial behaviours might arise from different reasons (LeSage and Pace 2009). First, agents might react to decisions that are taken by other agents in previous periods, following a time dependence motivation. Theoretically, there is no reason to exclude that those patterns occur also between agents located in different regions, as far as these regions are somehow linked to each other (e.g., by commuting), causing 'similar' regions to be clustered in space. Second, omitted variables issues may easily arise in regional modelling where unobservable factors (e.g., location amenities or fiscal incentives) can influence the outcome. Third, positive externalities can arise from neighbours influencing the behaviour of agents located in other regions.

With regard to the latter hypothesis, the scarce attention to spatial dependence is even more surprising, since the importance of local network externalities in influencing entrepreneurial decisions is well documented in the literature, and provides an interesting additional piece of explanation on why entrepreneurial activities tend to cluster geographically. Economies of scale and scope, and the resulting lower production and transaction costs, have been traditionally advocated as the main reasons behind spatial concentration of high entrepreneurship rates in certain areas (for an overview, see Minniti 2005). However, attempts to replicate these processes often failed, while regions showing similar conditions experience very different levels of entrepreneurial activity (Lomi 1995; Gimeno et al. 1997). Thus, other factors besides economic characteristics are expected to influence entrepreneurial activity.

In particular, a promising extension of classic models seeking to explain the geographical distribution of entrepreneurship is the one provided by sociological and organizational studies 
investigating the role of the social environment. Social networks and embeddedness have been shown to be crucial factors in individual decisions regarding entrepreneurship (Gulati 1998, 1999; Uzzi 1999). The reason why individuals are influenced by the local social environment in making entrepreneurial decisions is that they aim to increase the available set of information, so as to minimize risk. Furthermore, existing entrepreneurs may act as role models for self-employment candidates by providing (possibly) successful examples of the social condition that the potential entrepreneurs want to achieve. Theoretical and empirical research suggests a connection between the presence of role models and the emergence of entrepreneurs (for a brief overview, see Kolvereid 1996). Moreover, self-employed husbands have been shown to provide an incentive for married women to become self-employed (Caputo and Dolinsky 1998; Bruce 1999).

The influence of role models is described as a non-pecuniary network externality that is assumed to show increasing returns with adoption (Minniti 2005). In other words, the more entrepreneurs there are in one area, the less risky/ambiguous is - for a potential entrepreneur - the process of deciding whether to enter the market or not. Thus, the local entrepreneurial environment influences individual decisions regarding self-employment (Mueller 2006). Whether these network effects are bounded locally and restricted to the individual (or family) level, as argued by Aldrich and Zimmer (1986) and Cooper et al. (1989), or stretch beyond the individual's network and local labour markets, it is a question that our paper aims to address.

In our model explaining local differences in self-employment rates, we want to test the extent to which the influence of role models can be traced in the aggregate decision outcomes of the immigrants regarding self-employment. For this reason, we use data at the highest level of geographical disaggregation, the Census tract - which in Switzerland corresponds to the local unit or municipality - in order to capture the expected spatial spillovers of network effects due to the presence of entrepreneurs both (1) within the local units, and (2) in nearby local units.

With regard to point (1), we explicitly account for the self-employment rates of natives living in the same municipality, as we regard them as additional (potential) role models for immigrants. The natives can be simply seen as the most numerous ethnic group in every local unit, and their behaviour can be considered to be exogenous to the immigrants pool. Additionally, we expect this variable to capture all unobservable factors that affect local propensities toward entrepreneurship (e.g., the overall business climate, institutional facilities, etc.). In this framework, we should interpret the self-employment rates of natives as the baseline around which the local behaviour of immigrants is evaluated, that is, the level from which it deviates.

With regard to point (2), we can consider directly the self-employed rates of immigrants living in neighbouring municipalities, since existing ethnic entrepreneurs can influence decisions regarding self-employment of the immigrants living in adjacent communities. In particular, because our model is based on variables that are evaluated at the local unit in which immigrants live, we expect that the entrepreneurial decisions are taken also on the basis of the observed self-employment rates in communities where the immigrants have social relations, or where they move to in order to work or consume. Moreover, it has been widely shown that when using cross-sectional data at a highly disaggregated level, additional spatial dependence (e.g., local specific time-dependent variables such as adjustments of the tax levels, or unobservable factors such as location amenities and prestige, or infrastructure accessibility; see LeSage and Pace 2009) can occur, causing standard linear assumptions to fail. To accommodate spatial dependence, spatial econometric techniques are needed (Anselin 1988).

In addition, we want to evaluate the effects of local ethnic characteristics in determining the selfemployment rates of immigrants. Besides ecological characteristics that influence both natives and immigrants in their entrepreneurial decisions, as well as the geographical characteristics of the local unit, which are captured by the above-mentioned self-employment rates of natives, we argue that the characteristics of the local immigrant pool need to be considered as well.

Using Swiss Census data, Guerra et al. (2010) have highlighted the role played by ethnic concentration in influencing local self-employment rates. In particular, they show that local 
communities with high ethnic concentration (i.e., where the pool of immigrants is dominated by one or few nationalities) show higher rates of self-employed immigrants. Furthermore, local communities where the most important group is made up of immigrants coming from the traditional immigration countries (Germany, France or Italy) or speaking the same language as the (local) natives, show higher rates as well.

Additionally, we aim to show that geography plays a role in determining to what extent entrepreneurial activity is undertaken among immigrants. For instance, we find statistically significant effects for the characteristics of the local unit. In particular, a dummy variable discriminating communities located in cities and suburbs (against a baseline of rural areas) shows a negative coefficient, that is, self-employment among immigrants is significantly higher outside of the urbanized areas. The strong differences that we find between the two sub-samples of cities and rural areas lead us to partition our sample and to run separate models for the two spatial regimes.

The aim of this paper is to address the above issues by providing an analysis of the relevance of spatial spillovers in entrepreneurial decisions of immigrants for a cross-section of 2,490 Swiss municipalities in the year 2000. Poolability tests suggest splitting our data in two subsets, according to the urban-rural divide. Thus, we estimate two models for urban and rural local units. In addition, we provide complementary insights about the role played by local ethnic characteristics in enhancing business ownership rates. Understanding the relationship between natives and ethnic attitudes towards entrepreneurship, the local characteristics of the immigrant community and geography is crucial in a country where immigrants are about 20 per cent of the labour force and, unlike in most other countries, are scarcely attracted by the self-employment choice.

\section{The Model}

We propose a model that aims to explain local self-employment rates of immigrants as a function of (1) the local characteristics of the immigrant community and (2) the characteristics of the local unit in which the community is located. In its spatial extension, the model will consider also (3) the spatial effects due to the immigrant communities living in neighbouring municipalities.

\subsection{Local Characteristics of the Immigrant Community}

In this paper, our primary unit of analysis is the immigrant community, defined as the community of foreign-born individuals living in a specific local unit. In terms of the characteristics of the immigrant community, we consider its size, the degree of ethnic concentration and the characteristics of the most relevant ethnic group (referred to as the dominant one) as the main explanatory variables.

We account for the presence of ethnic enclaves, measured by an index of ethnic concentration, with the aim to measure the effect of cultural proximity on the self-employment rates of immigrants. Borjas (1986) has shown that immigrants living in ethnic enclaves are associated with higher business ownership rates, suggesting that concentration of ethnic groups in specific areas enhances opportunities for immigrants to become self-employed. ${ }^{1}$ Potential entrepreneurs located in ethnically concentrated communities are expected to benefit from comparative advantages in serving the needs of consumers of the same ethnic group (Light 1972). Furthermore, ethnic concentration may be favourable for business ownership, since it reduces conflicts and prejudices (Alesina and La Ferrara 2002, 2005). Moreover, the dominance of a particular ethnic group is expected to encourage self-employment through increased social interaction (Borjas 1986) and a reduction of transaction costs (Lazear 1999).

\footnotetext{
We do not control directly for the size of the ethnic community (e.g., by considering the share of immigrants on the total population), but we account for the different spatial regimes in which the communities live. Therefore, controlling for the urban-rural divide, we expect to indirectly capture size effects.
} 
In addition, we take into account the characteristics of the dominant ethnic group with regard to its immigration history and its linguistic proficiency. Following Guerra et al. (2010), we discriminate local units where the dominant nationality belongs to groups of recent immigration, since we expect those communities to be less integrated in the local labour market. Recent immigrants often lack first-hand knowledge, experience and capitals to start an economic activity on their own, as they need to accumulate savings and establish credit in order to obtain financing. We also control for local units where the dominant nationality is formed by immigrants of the same linguistic group as the natives. On the one hand, immigrant groups which are not proficient in the language spoken locally may be more likely to show high self-employment rates, as suggested by the isolated labour pool and disadvantaged theory (Light 1979; Evans 1989). On the other hand, linguistic integration could also encourage self-employment because of cultural proximity. Speaking the same language as the natives could provide immigrants with more business opportunities.

\subsection{Control Variables}

As control variables, we include additional information regarding the educational level, the gender and age composition, the average size of the family, and additional characteristics of the local immigrant community. The level of education is evaluated in the model through the share of immigrants who attained a professional degree. The underlying hypothesis is that communities with a higher share of professionally educated people will have higher self-employment rates. Education has been shown to positively influence the entrepreneurial decisions of immigrants, since it provides skills and knowledge that provide advantages in organizing and operating a business, as well as greater access to financial capital (Sanders and Nee 1996). On an individual basis, men have been shown to be more entrepreneurial than women (Meyer 1990; Blanchflower and Oswald 1991; Lindh and Ohlsson 1996). Therefore, keeping everything else constant, we expect local communities with a higher share of men to display higher rates of self-employment. Furthermore, many studies have suggested that there are some basic differences in the reasons why men and women opt for self-employment (Boden 1996; Carr 1996; Boden 1999). Individual probabilities to become self-employed increase with age, although at diminishing rates (see Rees and Shah 1986; Blanchflower and Oswald 1990; Sanders and Nee 1996 for the UK; Evans and Leighton 1989 for the United States). On the one hand, very young people do not own the necessary skills and professional contacts, and are less likely to dispose of sufficient capitals to open their own business. On the other hand, older persons tend to lose interest in becoming entrepreneurs (Rees and Shah 1986). In our model, we include the average age of immigrants, which is expected to be associated with higher self-employment rates, along with its square to catch nonlinearities.

\subsection{Characteristics of the Local Unit}

The characteristics of the local unit in which the immigrants live are also included, following the idea that local conditions influence attitudes towards entrepreneurship. In particular, we include the self-employment rate of natives living in the same local unit, in order to investigate the extent of role models influences. On the one hand, we expect the natives to provide successful examples regarding the local self-employment experience. On the other hand, the native self-employment rate is supposed to capture unobserved ecological variables that eventually influence the entrepreneurial behaviour of both immigrants and natives.

Furthermore, we evaluate the urban-rural gap by means of a dummy variable splitting our sample in two groups: cities and suburbs are compared to rural areas. Following the results of a poolability test performed on the basis of this dummy variable (see Section 4.2), we will consider and estimate two separate models for the urban and rural milieus. 
Finally, we include a proxy for the accessibility of the local units using by the minimum elevation of the area in order to discriminate for areas that are easily linked to other areas or are rather isolated (as is the case of the municipalities in the Alpine region).

\subsection{Characteristics of Neighbouring Units and Spatial Extensions}

In addition to the natives' self-employment rates, our identification strategy completes the analysis by considering the entrepreneurial behaviour of immigrants living in the surrounding areas. Thus, we include in our model the average rate of self-employed immigrants living in neighbouring municipalities. Our hypothesis is that existing ethnic entrepreneurs can influence decisions regarding self-employment of immigrants living in neighbouring communities. In particular, we expect to observe similarities in self-employment rates among local communities between which commuting flows or intense social relations occur.

In addition to a model specification motivation, there is also an econometric motivation to explicitly include such spatial spillovers in our model. The spatial econometrics literature has shown that OLS estimation is inappropriate for models incorporating spatial effects. As shown in Cliff and Ord (1981) and Anselin (1988), models of spatial dependence are used to account for direct influence from spatial neighbours or spillovers between cross-sectional units of observation. From an empirical viewpoint, there are several methods to incorporate spatial dependence in a model. We choose to rely on the model that incorporates only the spatial autocorrelation term $\rho$, which is expected to capture spatial spillovers pertaining to the dependent variable (selfemployment rates of neighbouring communities) and residual unobserved common factors.

It is important to underline, at this stage - as it is central to our identification strategy - that because we include the self-employment rates of natives and regional characteristics in our model, we already control for ecological variables that influence both immigrants and natives.

\subsection{The Full Model}

In summary, our model is made up of the following components:

- the immigrant local characteristics;

- a set of control variables:

○ for the composition of the local immigrant community;

o for geography;

- the self-employment rate of the natives;

- the average self-employment rate of immigrants living in neighbouring municipalities.

Our model can then generically be written as follows:

$$
\text { FOREMPSE }_{i}=f\left(\text { WIEMPSE }_{i}, \text { FOREMPSE }_{j}, X_{k, i}, C_{s, i}, V_{t, i}\right)
$$

where FOREMPSE $E_{i}$ is the self-employment rate of immigrants registered in the local community $i$, with $i=1, \ldots, N$; SWIEMPSE $E_{i}$ is the self-employment rate of the natives in unit $i$ FOREMPSE $_{j}$ is the self-employment rate of immigrants living in the neighbouring units $j ; X_{k, i}$ is a vector containing the $k=1, \ldots, K$ characteristic of the local ethnic community $i ; C_{s, i}$ contains the set of $s=1, \ldots, S$ controls for the local ethnic community; $V_{t, i}$ describes the $t=1, \ldots, T$ geographical characteristics of the local unit.

In order to estimate such a model, we may resort to spatial econometric methods. Following Anselin (1988), we design a spatial lag or spatial autoregressive model (SAR). Our model can then be estimated as: 


$$
r_{i}=\frac{Y_{i}}{n_{i}}=\rho W r+\beta_{0}+\beta_{1 k} X_{k, i}+\beta_{2 k} C_{s, i}+\beta_{3 t} V_{t, i}+\varepsilon_{i},
$$

where $r_{i}=\frac{Y_{i}}{n_{i}}$ is the self-employment rate of immigrants registered in the local community $i$, computed as the number of self-employed immigrants $Y_{i}$ divided by the related active population $n_{i}$; $\rho$ is the coefficient measuring the dependence of the dependent variable from the average rates reported in neighbouring units $j\left(r_{j}\right) ; W$ is a properly defined spatial weights matrix; $\beta_{0}$ is the intercept of the model; $\beta_{1 k}$ is the regression parameter associated to the $k$ th characteristic of local ethnic communities expressed in matrix $X ; \beta_{2 s}$ is the parameter for the $s$ th control variable in matrix $C ; \beta_{3 t}$ is the parameter for the $t$ th characteristic of the local units, given in matrix $V$. Finally, $\varepsilon_{i}$ is the error term for unit $i$, which is expected to meet the usual assumption $\varepsilon_{i} \sim$ i.i.d. $\left(0, \sigma^{2}\right)$.

\section{Data}

We consider the number of self-employed immigrants recorded by the Swiss Federal Population Census for 2,490 municipalities in the year $2000 .^{2}$ The sample includes 46,162 entrepreneurs among 892,300 (5.2 per cent) immigrants who are considered active on the labour market. Table 1 provides an overview of selected descriptives.

The number of ethnic entrepreneurs (\#FOREMPSE) ranges from 0 to 3,310, the latter figure being registered in the city of Zurich (4.7 per cent of 69,937 active immigrants). Self-employment rates for each local community (FOREMPSE) were computed dividing the number of selfemployed immigrants (all sectors, both with and without employees) by the related active population, and range from 0 to 1 . Figure 1 shows their spatial distribution across Swiss municipalities (our unit of analysis), suggesting that higher rates are observed mostly in the proximity of the Swiss borders, that is, where considerable cross-border commuting exists. The average rate across all municipalities is 8 per cent, which is considerably lower than the average rate observed for the natives (15 per cent, SWIEMPSE). In our sample, the average (immigrant) population size per local unit (\#FORACTIVE) is 358, varying from 5 to 69,937.

As for the characteristics of the local ethnic communities, the average size of the ethnic community (FORACTIVE, not included in the model) is rather small, 14.1 per cent on the total active population, but varies considerably, in particular upwards (up to 70.3 per cent). The distribution of different nationalities in the local communities (HERFINDAHL) 3 highlights a prevalence of communities with a rather diverse ethnic composition. The average indicator for ethnic concentration is 0.25 , and ranges from 0 (no ethnic concentration) to 1 (full concentration; i.e., all active immigrants are of the same nationality). Local unemployment rates among immigrants (FORUNEMP) are 6.8 per cent on average.

2 We excluded local units with less than five active immigrants (406 out of the 2,896 local units reported in the Census) in order to decrease the heterogeneity in the sample and avoid high shares of unreliable extreme values.

3 We use an adaptation of the Herfindahl-Hirschman index (Hirschman 1945; Herfindahl 1950), originally used as a measure of trade or industrial concentration, in order to measure ethnic concentration. For each local unit $i(i=1$, $\ldots, N)$, we compute the index as: HERFINDAHL $=\sum_{p=1}^{P} s_{i, p}^{2}$, where $s_{i, p}$ is the share of active immigrants of the ethnic group $k$ on the total active immigrants within local unit $i . P$ is set to seven, for the main immigrant groups in Switzerland (Italians, Germans, French, Portuguese, Spanish, Turkish and former Yugoslavians). 
Table 1. Selected descriptive statistics

\begin{tabular}{lllll}
\hline & Mean & St. dev & Min & Max \\
\hline Dependent variable & & & & \\
FOREMPSE (\%) & 7.97 & 7.53 & 0.00 & 100.00 \\
- Numerator: \#FOREMPSE & 18.54 & 102.15 & 0.00 & $3,310.00$ \\
- Denominator: \#FORACTIVE & 358.35 & $2,033.94$ & 5.00 & $69,937.00$ \\
Local ethnic characteristics & & & & \\
FORACTIVE (\%) & 14.14 & 9.35 & 0.95 & 70.34 \\
HERFINDAHL & 0.25 & 0.14 & 0.01 & 1.00 \\
Controls & & & & \\
FORUNEMP (\%) & 6.76 & 5.79 & 0.00 & 69.23 \\
Local unit's characteristics & & & & \\
SWIEMPSE & 15.38 & 5.49 & 0.00 & 52.50 \\
- Numerator: \#SWIEMPSE & 144.25 & 417.64 & 0.00 & $15,709.00$ \\
- Denominator: \#SWIACTIVE & $1,212.30$ & $3,954.86$ & 13.00 & $142,452.00$ \\
\#TOTACTIVE & $1,570.75$ & $5,914.73$ & 18.00 & $212,389.00$ \\
Factors & No. of local units & & & \\
RECENTIMMIGR: yes & 1,154 & & & \\
LANGPROALL: yes & 873 & & & \\
URBAN: Rural areas & 1,524 & & & \\
URBAN: Cities and suburbs & 966 & & & \\
Total local units & 2,490 & & & \\
\hline
\end{tabular}

Notes: \# defines counts; \% defines percentages.

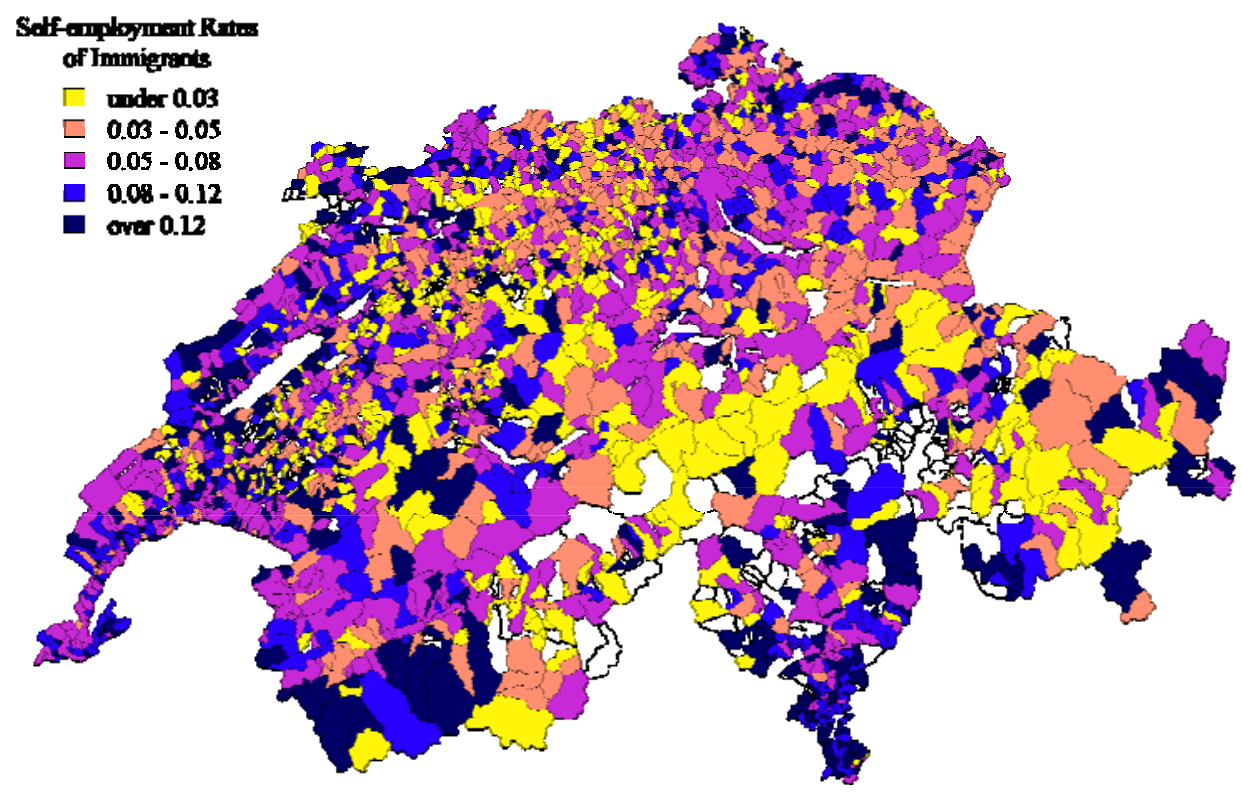

Figure 1. Cloropleth quantile map of immigrant self-employment rates in Swiss municipalities

Self-employment rates among natives (SWIEMPSE) are persistently higher than the ones observed for immigrants, with an average of 15.4 per cent in the sample and a symmetric distribution ranging between the extremes of 0 and 52.5 per cent. 
In 1,154 of the 2,490 local communities investigated, the dominant nationality is made up of socalled newcomers (RECENTIMMIGR). ${ }^{4}$ In 873 immigrant communities, the most relevant nationality speaks the same language of the natives (LANGPROALL). ${ }^{5}$ Finally, out of the total number of local units censed, 1,524 have rural characteristics, while 966 are cities or suburbs (URBAN).

Because of the very different industrial structure and labour force characterization typical of urbanized and rural areas, we may expect the characteristics of immigrants to vary as well, according to the urbanization characteristics of the municipalities. Table 2 presents average values for the two subsamples obtained by splitting our data according to the urban-rural divide, while Figure 2 provides information on the geographical location of the urbanized and rural units.

Table 2. Selected descriptive statistics for the urban/suburb and rural subsamples

\begin{tabular}{lll}
\hline & $\begin{array}{l}\text { Urban units } \\
\text { Mean (St. dev) }\end{array}$ & $\begin{array}{l}\text { Rural units } \\
\text { Mean (St. dev) }\end{array}$ \\
\hline $\begin{array}{l}\text { Dependent variable } \\
\text { FOREMPSE (\%) }\end{array}$ & $7.88(5.01)$ & $8.03(8.76)$ \\
- Numerator: \#FOREMPSE & $40.47(161.38)$ & $4.64(7.34)$ \\
- Denominator: \#FORACTIVE & $777.81(3,215.33)$ & $92.47(167.21)$ \\
Local ethnic characteristics & & \\
FORACTIVE (\%) & $18.50(9.90)$ & $11.38(7.83)$ \\
HERFINDAHL & $0.22(0.14)$ & $0.26(0.14)$ \\
Controls & & \\
FORUNEMP (\%) & $7.00(3.91)$ & $6.60(6.71)$ \\
Local unit's characteristics & & \\
SWIEMPSE & $12.57(3.71)$ & $17.16(5.69)$ \\
- Numerator: \#SWIEMPSE & $240.22(651.33)$ & $83.41(81.92)$ \\
- Denominator: \#SWIACTIVE & $2,252.39(6,166.65)$ & $553.02(587.88)$ \\
\#TOTACTIVE & $303,020(9,269.18)$ & $645.50(725.81)$ \\
Factors & No. of local units & No. of local units \\
RECENTIMMIGR: yes & 353 & 801 \\
LANGPROALL: yes & 350 & 523 \\
Total local units & 966 & 1524 \\
\hline
\end{tabular}

Notes: \# defines counts; \% defines percentages.

While the average rates of immigrant self-employment are rather similar for the two groups (with a greater standard deviation for rural areas), the same rates for the Swiss natives are instead rather different (13 vs 17 per cent), suggesting that within the two contexts the behaviour of the natives may influence the one of the immigrants to different extents, keeping everything else constant. A further clear difference between the two sub-samples is that rural areas appear to have welcomed higher shares of 'newcomers'. The rural local units with a dominant nationality of recent immigration are more than half (they are only about one third in urbanized areas). Likewise, in 69 per cent of the total cases (801 out of 1,154), local units with a non-traditional dominant ethnic group are rural. Finally, rural units are predominant from a numerical viewpoint, as they represent about 61 per cent of the sample.

4 We consider as newcomers immigrants belonging to more recent waves (i.e., the Spanish, Portuguese, Yugoslavians and the Turkish), as opposed to traditional immigrants, coming from the countries surrounding Switzerland (Italians, Germans and French).

5 The language proficiency of the dominant group is proxied by a dummy variable that takes the value of 1 if the dominant nationality belongs to the same linguistic group as the locals, and 0 otherwise. 


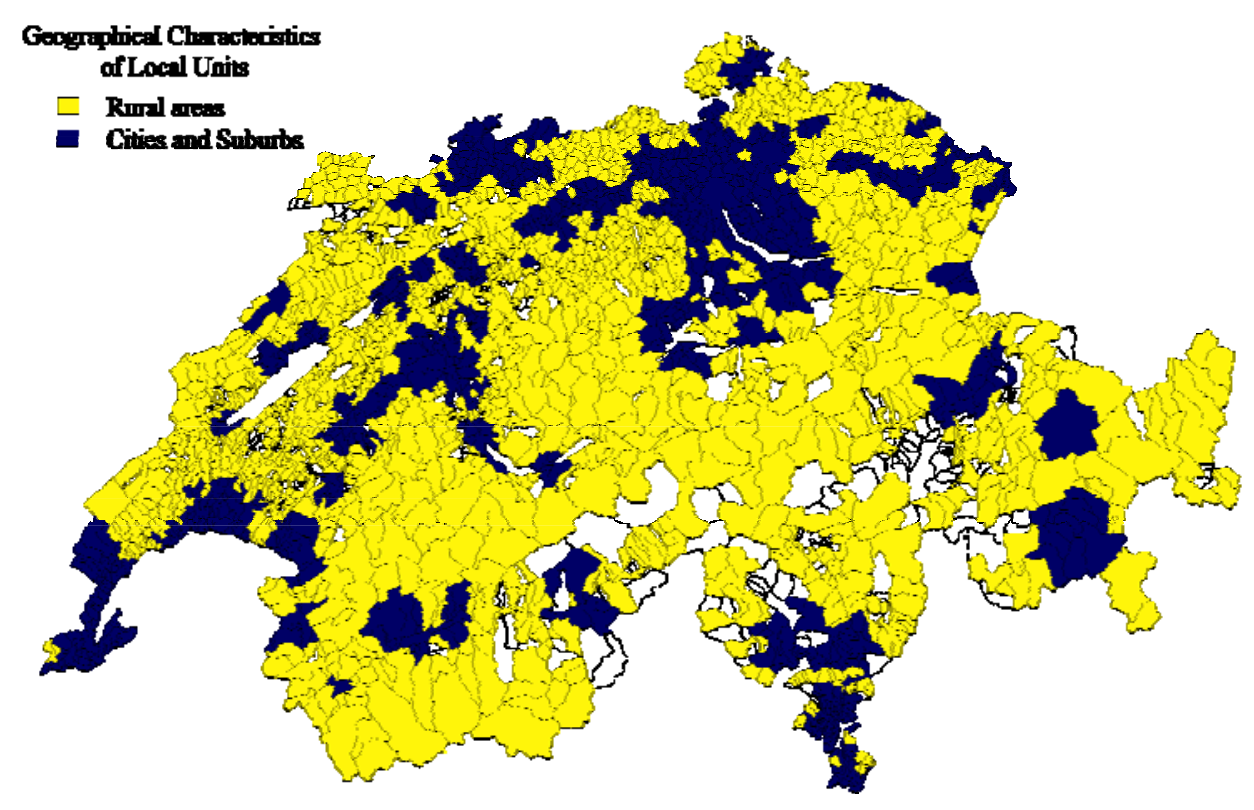

Figure 2. The geographical distribution of urbanized and rural local units

\section{Empirical Findings}

The existing literature on ethnic self-employment, which mostly seeks to explain differences among ethnic groups in individual probabilities to become entrepreneur, suggests that differences are partly explained by group characteristics such as family background (Sanders and Nee 1996), location in ethnic enclaves (Borjas 1986), linguistic proficiency (Evans 1989), taxation levels (Blau 1987), and ethnicity (for an overview, see Yuengert 1995).

We investigate local differences in immigrant self-employment rates, in order to uncover which local characteristics encourage entrepreneurship, and we concentrate our analysis on the variables that may detect the presence of family or ethnic networks as important factors. We proceed in three steps. First, we estimate our model for the full sample of Swiss municipalities. Second, following the results of an urban/rural poolability test, allowing differences in parameters between ethnic communities located in urbanized and rural areas, we carry out two separate estimations for our model. Third, in order to investigate the geographical extent of spatial network effects, we perform a spatial sensitivity analysis using different definitions of proximity (e.g., contiguity, distance or travel times) and varying degrees of spatial interaction.

Since our analysis involves rates as the dependent variable and the rates are computed on small areas with (sometimes) relatively scarce population, we expect our dependent variable not to respect the assumptions typical of linear regression models (Gaussian distribution and homoskedasticity). More appropriate models for proportions are provided within the family of generalized linear models (GLM). However, since tests for spatial autocorrelation, and in particular the use of Moran's $I$ test for GLM regression residuals, are still speculative and provisional (Bivand et al. 2008), we choose to rely on linear models and on an appropriate transformation of the dependent variable.

We may expect the counts $Y_{i}$ (in our case the number of self-employed immigrants) to follow a binomial distribution with $E\left(\frac{Y_{i}}{n_{i}}\right)=r_{i}$ and $\operatorname{var}\left(\frac{Y_{i}}{n_{i}}\right)=\frac{r_{i}\left(1-r_{i}\right)}{n_{i}}$. However, for small $r_{i}$, the variance is proportional to the mean, suggesting a square-root (or log) transformation to smooth out heteroskedasticity. Furthermore, the presence of spatial autocorrelation (i. e., the fact that the counts 
of self-employed immigrants are sums of spatially dependent binomial random variables) requires a stronger transformation (Cressie 1993). Thus, we transform the dependent variable as follows:

$$
Z_{i}=\log \left(\frac{1000\left(Y_{i}-1\right)}{n_{i}}\right)
$$

The proposed log-transformation has the advantage that it helps to discriminate between local units with a small number of self-employed immigrants $\left(Y_{i} \leq 1\right)$ but with different population size (Waller and Gotway 2004, p. 348), as in our case. This transformation contributes to reshaping a very skewed distribution, with many zeros, into one that is reasonably symmetric and approximately normally distributed, with a mean value of 4.45 , a median value of 4.41 and a standard deviation of 0.72 (see Figure 3).
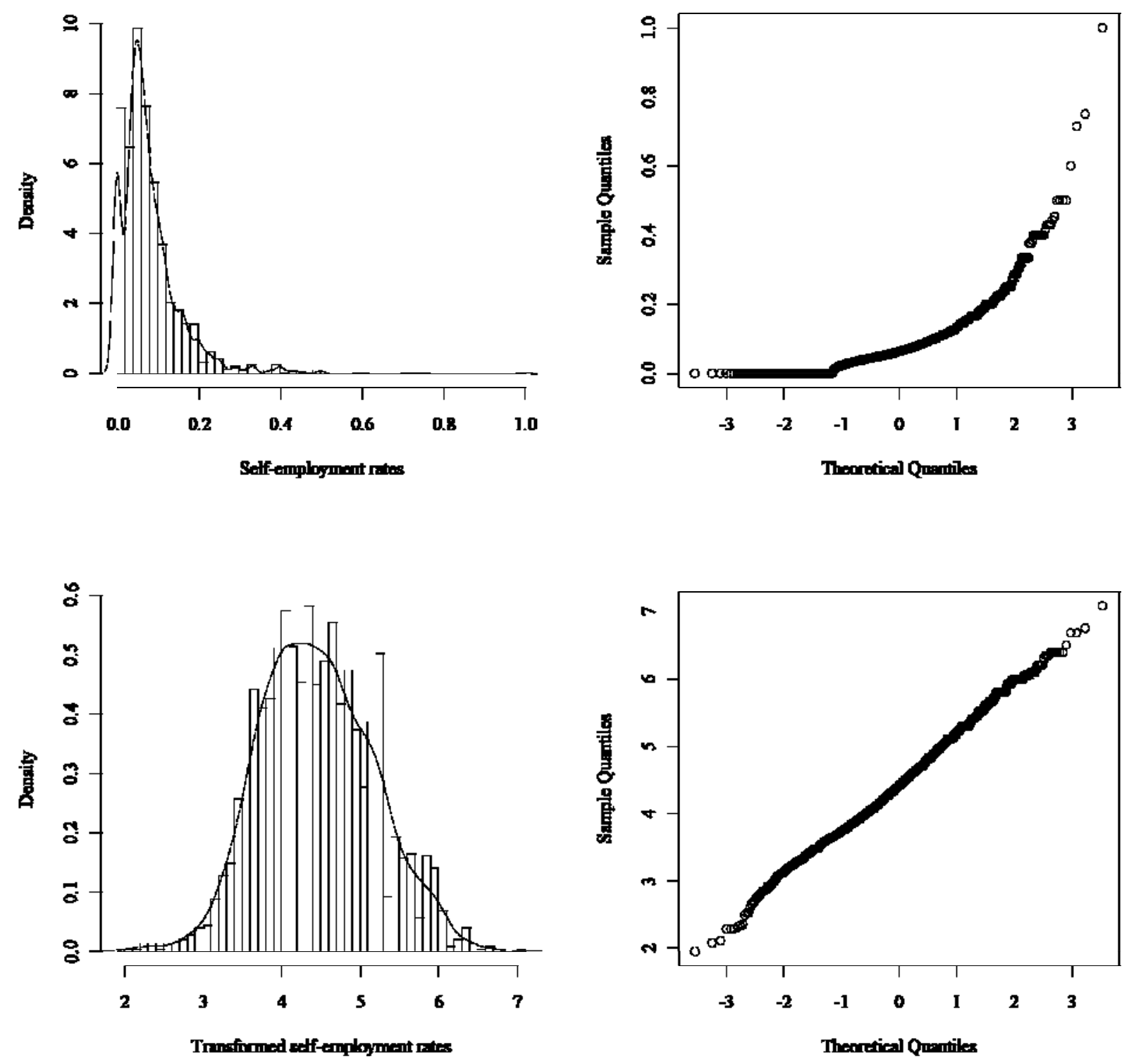

Figure 3. Histograms and Q-Q plots of the untransformed (above) and transformed (below) immigrant self-employment rates for the full sample of Swiss municipalities 
Among our set of covariates, many show a non-normal distribution. Thus, we choose to transform these variables as well, using the conventional log-transformation: $x^{*}=\log (x+0.0001){ }^{6}$

\subsection{Pooled Model Results}

In the first step of our analysis (see above), we estimate our model for the full sample of 2,490 Swiss municipalities. Table 3 presents the results for three nested specifications, which are sequentially estimated as follows:

Table 3. Regression results for the pooled models

\begin{tabular}{|c|c|c|c|}
\hline & Model 1 & Model 2 & Model 3 \\
\hline \multicolumn{4}{|l|}{ Local ethnic characteristics } \\
\hline $\log (\mathrm{HERFINDAHL})$ & $-0.04(0.03)$ & $-0.05(0.03)^{*}$ & $-0.06(0.02)^{* * *}$ \\
\hline RECENTIMMIGR & $-0.15(0.03)^{* * *}$ & $-0.17(0.03) * * *$ & $-0.17(0.03)^{* * *}$ \\
\hline LANGPROALL & $0.32(0.03)^{* * *}$ & $0.25(0.04)^{* * *}$ & $0.23(0.03)^{* * *}$ \\
\hline \multicolumn{4}{|l|}{ Controls } \\
\hline $\log ($ FORACTIVEMEN) & $0.05(0.09)$ & $0.04(0.1)$ & $0.04(0.07)$ \\
\hline $\log$ (FORACTIVEMARRIED) & $-0.08(0.05)^{*}$ & $-0.04(0.07)$ & $-0.04(0.04)$ \\
\hline log(FORACTIVENON) & $-0.04(0)^{* * *}$ & $-0.04(0)^{* * *}$ & $-0.04(0)^{* * *}$ \\
\hline $\log ($ FOREMPTER $)$ & $0.08(0.03)^{* * *}$ & $0.04(0.04)$ & $0.04(0.02)^{* *}$ \\
\hline FORACTIVEAGE & $6.58(0.75)^{* * *}$ & $5.44(0.74) * * *$ & $5.10(0.63)^{* * *}$ \\
\hline FORACTIVEAGE $* * 2$ & $2.40(0.79)^{* * *}$ & $1.95(0.73)^{* * *}$ & $1.91(0.57)^{* * *}$ \\
\hline $\log$ (FORACTIVECHIL) & $-0.38(0.09) * * *$ & $-0.38(0.1)^{* * *}$ & $-0.36(0.07)^{* * *}$ \\
\hline $\log$ (FORACTIVEPROFEDU) & $-0.03(0.01)^{* * *}$ & $-0.03(0.01)^{* * *}$ & $-0.02(0.01)^{* * *}$ \\
\hline $\log$ (FORACTIVEACCAEDU) & $-0.02(0.01)^{* *}$ & $-0.01(0.01)^{* *}$ & $-0.01(0.01)^{* *}$ \\
\hline $\log (\mathrm{FORUNEMP})$ & $-7.42(0.69)^{* * *}$ & $-6.55(0.82)^{* * *}$ & $-6.26(0.6)^{* * *}$ \\
\hline $\log ($ FORUNEMP $) * * 2$ & $5.14(0.7)^{* * *}$ & $5.18(0.7)^{* * *}$ & $5.28(0.57)^{* * *}$ \\
\hline \multicolumn{4}{|l|}{ Local unit's characteristics } \\
\hline $\log (\mathrm{ZMIN})$ & $0.12(0.04)^{* * *}$ & $0.04(0.05)$ & $0.04(0.04)$ \\
\hline URBANsubcities & $-0.16(0.03)^{* * *}$ & $-0.05(0.04)$ & $-0.04(0.03)$ \\
\hline $\log ($ SWIEMPSE) & - & $0.44(0.14)^{* * *}$ & $0.42(0.03)^{* * *}$ \\
\hline$\rho$ & - & - & $0.15(0.02)^{* * *}$ \\
\hline (Intercept) & $3.77(0.29)^{* * *}$ & $5.06(0.49)^{* * *}$ & $4.36(0.29)^{* * *}$ \\
\hline Residual standard error (dof) & $0.55(2,473)$ & $0.53(2,472)$ & $0.52(2,471)$ \\
\hline$R^{2}\left(\right.$ Adjusted $\left.R^{2}\right)$ & $0.43(0.42)$ & $0.46(0.46)$ & - \\
\hline AIC & $4,100.17$ & $3,946.33$ & $3,903.74$ \\
\hline F-test (Model 2 vs Model 1) & - & $159.65 * * *$ & - \\
\hline Likelihood ratio test (Model 3 vs Model 1) & - & - & $44.587 * * *$ \\
\hline
\end{tabular}

Notes: $* * *, * *$ and $*$ denote significance at the 1,5 and 10 per cent levels.

- Model 1: OLS model, including the immigrant pool local characteristics (HERFINDAHL, RECENTIMMIGR, LANGPROALL), the control variables for the composition of the local immigrant community (FORACTIVEMEN, FORACTIVEMARRIED, FORACTIVENON, FOREMPTER, FORACTIVEAGE, FORACTIVECHIL, FORACTIVEPROFEDU, FORACTIVEACCAEDU, FORUNEMP), and the controls for geography (ZMIN, URBANsubcities);

- Model 2: OLS model with the same specification as Model 1, and including the self-employment rates of the natives (SWIEMPSE);

6 The 0.0001 constant added to selected variables before taking logs is elided in the remaining text. 
- Model 3: Spatial lag model, with same specification as Model 2, estimated by maximum likelihood (ML).

From Table 3, it is evident that the inclusion, in Model 2, of the native self-employment rates (SWIEMPSE) leads to a significant statistical improvement in model fit (measured by means of $R^{2}$ and the Akaike information criterion (AIC), as confirmed also by an F-test. Additionally, Model 3, including the average rates observed in neighbouring units, ${ }^{7}$ which have a positive and significant parameter, shows a further improvement when examining the AIC. A likelihood ratio test between of Model 3 against Model 2 provides further confirmation. Additionally, our estimates are rather stable - in both sign and size - over the three model specifications. Consequently, we will henceforth limit ourselves to commenting the results obtained for the full model (Model 3).

Our estimation results generally show that the parameter estimates for some of the control variables tend to decrease in size or to altogether lose significance (e.g., ZMIN and URBANsubcities) once the natives self-employment rates are considered, confirming that this variable - as expected - is convoluted with most (measurable and non-measurable) ecological factors that may influence all entrepreneurs. Likewise, the parameter attenuation observed increases when moving to Model 3.

More in detail, with regard to the local ethnic characteristics, the regression parameter for the ethnic concentration index suggest a negative effect on the dependent variable, which however only becomes significant in Model 3. If the locally dominant nationality is made up of newcomers, the estimated self-employment rates are smaller. This result is consistent with the hypothesis that ethnic communities of more recent (historical) immigration face greater obstacles towards selfemployment. Language proficiency, instead, has a significant and positive effect on local selfemployment rates, suggesting that linguistic integration with the locals (the natives) is an important factor for ethnic communities.

As for the control variables, the regression parameters for the share of male immigrants and for the share of active immigrants reported as married are non-significant. The variable accounting for the share of immigrants without a permanent residence permit is negatively associated with local self-employment rates. The industrial composition of the labour force does not has a positive, but rather small and unstable, parameter. The average age of the immigrant community increases selfemployment rates, at a more-than-linear rate (the quadratic term is also positive and significant), while the negative parameter for the average household size may be seen as reducing the positive effect of age, because of the risk aversion behaviour tied to the presence of children. The results of the pooled model also suggest that a higher share of professionally or academically educated immigrants implies less self-employed, probably because of the opportunity cost associated with setting up an independent business. This finding is in contrast with the one of Guerra et al. (2010), who find a positive parameter estimate for the same variables. Finally, local unemployment rates are negatively associated with the dependent variable with respect to the linear term, but the relationship becomes positive for the quadratic term, leading to a U-shaped relationship that suggests that only a high-unemployment environment pushes the immigrants towards selfemployment.

Among the local factors, we find that communities located in the Alpine regions do not seem to behave differently (the regression parameter for altitude is non-significant). Also, in Model 1, ethnic communities located in urban areas show significantly lower self-employment rates than the ones located in the countryside. However, this difference in intercepts disappears when considering the self-employment rates of the natives (Models 2 and 3), confirming again that most ecological factors are included in our model by means of the latter variable. Needless to say, the natives' rates are positively and strongly significantly correlated with the entrepreneurial activity of immigrants. Finally, the spatial dependence parameter $\rho$ estimated in Model 3 is positive and significant as well.

For the empirical estimation of the coefficient of spatial autocorrelation we use a row-standardized spatial weights matrix based on a first-order queen definition of contiguity. 
Not surprisingly, its size is relatively small, also by comparative terms with respect to the parameter estimate for the natives' rates (unobserved ecological variables have already been included implicitly by the key variable of Model 2). These findings suggest that: (i) our hypothesis on the influence of role models both within and outside the municipality of reference holds; and that (ii) the effect of role models may occur not only between immigrants, but also across nationalities (including the natives).

\subsection{Unpooled Model Results}

The results presented in Table 3 assume poolability of our baseline model at the regional level. However, there are reasons to believe that ethnic communities located in rural areas behave differently from their urban counterparts. In particular, there are strong differences between rural and urban areas with regard to immigrant characteristics and their spatial distribution. As suggested by the descriptive statistics given in Table 2, we may expect to find different parameter estimates for the urban and rural subsamples, that is, the determinants of immigrant self-employment may differ. This hypothesis does not necessarily regard the intercept, as proven by our findings for the baseline model, in which the URBANsubcities dummy variable becomes non-significant once we augment Model 1.

We test for poolability of our baseline model by estimating an unrestricted model and testing it against the restricted model. Therefore, the hypothesis $H_{0}$ we test here is:

$$
\beta_{U}=\beta_{R}=\beta
$$

where $\beta_{U}$ is the vector of regression parameters for the submodel estimated only for urbanized areas, and $\beta_{R}$ is its counterpart for the rural areas; $\beta$ is ideally the vector of parameters for the restricted model. The restricted and unrestricted models are clearly nested, as the restricted model is a special case of the unrestricted one. If $H_{0}$ is rejected up to a satisfying probability, then we must conclude that the restricted model is misspecified, and that separate estimations should be carried out.

We obtain the unrestricted model by interacting the URBANsubcities dummy variable identifying urbanized and rural areas with all remaining explanatory variables, and we perform an F-test between the two models, the number of restrictions applied being 16 (2472 vs 2456 residual degrees of freedom). The $\mathrm{F}$ statistic is equal to 5.954, and leads to a highly significant rejection of $\mathrm{H}_{0}{ }^{8}$ Consequently, separate models are estimated for the urban/suburb and rural subsamples, whose regression results are reported in Table 4.

Two findings can be drawn from these additional regressions. Our first finding is that the unpooled models confirm the significance and (approximately) the size of the parameter estimates for our key variables. Both the self-employment rates of the natives (SWIEMPSE) and the spatial dependence parameter $\rho$ are consistent with the previous estimation. The estimates for the former differ in that the impact of the natives' behaviour seems to be greater in an urban context than in a rural one.

The second finding is that, indeed, the two models differ under many respects, in both significance and size of the parameters estimated for the control variables. The unstable result found in Table 3 for the ethnic concentration index (HERFINDAHL) breaks down here to the nonsignificant parameter for the urbanized subsample and the significant and negative one for the rural subsample, implying that a stronger ethnic concentration is less relevant in the cities, while in a less dense geographical context increased chances for interaction with other immigrants of the same

\footnotetext{
Further poolability tests (Chow and Roy-Zellner tests, not reported) confirm our finding. For computational reasons, we perform all poolability tests on Model 2, since spatial lag models imply a number of complications with regard to poolability testing. However, the similar AIC of the two models, as well as the high significance of the test result, make us confident that an identical result would be found for Model 3.
} 
nationality reduces job search costs, and consequently leads to an increased propensity towards wage employment. In a rural context, clearly, ethnic entrepreneurship aiming targeting the needs of the immigrants is less desirable, given the lowest density. Language proficiency, instead, becomes more relevant - as it is typical - outside of the melting-pot environment typical of urban contexts.

Table 4. Regression results for the unpooled models

\begin{tabular}{lcc}
\hline & Model 3 & Model 3 \\
& Urban/suburb & Rural \\
\hline Local ethnic characteristics & & $-0.09(0.03)^{* * *}$ \\
$\log ($ HERFINDAHL) & $0.00(0.03)$ & $-0.17(0.05)^{* * *}$ \\
RECENTIMMIGR & $-0.14(0.03)^{* * *}$ & $0.23(0.05)^{* * *}$ \\
LANGPROALL & $0.13(0.04)^{* * *}$ & \\
Controls & & $-0.03(0.08)$ \\
$\log ($ FORACTIVEMEN) & $0.70(0.15)^{* * *}$ & $-0.05(0.05)$ \\
$\log$ (FORACTIVEMARRIED) & $0.03(0.14)$ & $-0.04(0.0 \times x 1)^{* * *}$ \\
$\log ($ FORACTIVENON) & $-0.04(0.01)^{* * *}$ & $0.04(0.02)^{* *}$ \\
$\log ($ FOREMPTER) & $0.24(0.07)^{* * *}$ & $3.81(0.67)^{* * *}$ \\
FORACTIVEAGE & $2.71(0.56)^{* * *}$ & $1.53(0.64)^{* *}$ \\
FORACTIVEAGE ** 2 & $0.18(0.41)$ & $-0.43(0.09)^{* * *}$ \\
$\log ($ FORACTIVECHIL) & $-0.11(0.14)$ & $-0.03(0.01)^{* * *}$ \\
$\log ($ FORACTIVEPROFEDU) & $0.07(0.02)^{* * *}$ & $-0.01(0.01)^{* *}$ \\
$\log ($ FORACTIVEACCAEDU) & $-0.02(0.01)$ & $-5.98(0.65)^{* * *}$ \\
$\log ($ FORUNEMP) & $-2.07(0.44)^{* * *}$ & $6.31(0.64)^{* * *}$ \\
$\log ($ FORUNEMP) $* * 2$ & $0.61(0.43)$ & \\
Local unit's characteristics & & $0.06(0.05)$ \\
$\log ($ ZMIN) & $0.05(0.05)$ & $0.36(0.04)^{* * *}$ \\
$\log ($ SWIEMPSE) & $0.54(0.06)^{* * *}$ & $0.07(0.02)^{* * *}$ \\
$\rho$ & $0.11(0.03)^{* * *}$ & $4.54(0.38)^{* * *}$ \\
Intercept & $5.19(0.43)^{* * *}$ & $-1,342.96$ \\
\hline Log-likelihood & -465.26 & 0.57 \\
ML residual standard deviation $(\sigma)$ & 0.39 & $2,723.92$ \\
AIC & 968.52 &
\end{tabular}

Notes: ${ }^{* * *},{ }^{* *}$ and ${ }^{*}$ denote significance at the 1,5 and 10 per cent levels.

The gender balance appears to be relevant only in the urban context instead, as well as the industrial specialization in the tertiary sector (as it may be expected). The negative and significant parameters for education in the rural model reinforces the finding for the industrial specialization variable, supporting the idea that different types of required skills imply different types of businesses managed by the immigrant entrepreneurs. This finding deserves, in our view, further investigation, which goes beyond the aim of this paper.

In the urban context, the number of children does not seem to act as a deterrent to selfemployment, given the existence of a possible back-up plan based on wage employment. The effects of age appear to be much greater - and quadratic - in rural areas. This finding can be explained by the fact that in most cases younger immigrants - whether they have wage- and selfemployment ambitions - are attracted to the cities, leaving the rural alternative mostly to older immigrants. Finally, higher unemployment rates are associated with lower self-employment rates in the urban context (greener economic pastures attract entrepreneurs). The U-shaped relationship found in Table 3 for the pooled model is confirmed only for the rural context, suggesting that the common self-employment-out-of-unemployment hypothesis can be supported in this case, again 
most likely because the sparser network relationships in rural areas diminish the hopes of finding a (new) wage job.

\section{Spatial Sensitivity Analysis}

The analyses presented in Section 4 showed that spatial network effects can be hypothesized for Swiss municipalities when it comes to self-employment choice of immigrants. We want to investigate at which these effects actually occur. Do they arise only at a very local scale? If that is the case, we may infer that family-related contacts and social networks play a role (push effects). Do these spatial effects occur instead at a larger geographical scale (e.g., local labour markets)? In this case, it is likely that market effects, or further unobserved labour market characteristics are relevant (pull effects). It is good practice to assess the extent and the shape of spatial dependence in the observations being analysed by means of an exploratory spatial data analysis (Haining 1990; Bailey and Gatrell 1995; Anselin 1998, 1999; Le Gallo and Ertur 2003). This set of techniques provides measures of global and local spatial autocorrelation.

We first test the rates of self-employed immigrants in the whole sample (before partitioning it) for global spatial autocorrelation using Moran's $I .{ }^{9}$ Statistical tests were performed using three different spatial weights matrices ( $k$-nearest neighbours $(\mathrm{KNN})$, queen contiguity neighbours, and distance threshold neighbours) ${ }^{10}$ using the common row-standardization and under the randomisation assumption (Bivand et al. 2008, p. 262). In order to evaluate the extent of spatial dependence in a more realistic way, particularly in a country like Switzerland where, for instance, contiguous units may not have a direct road connection (as on the Alps), spatial weights matrices based on inverse travel times distances were computed and tested as well, under the assumptions of both road congestion and no congestion. ${ }^{11}$ The results of the tests show that the spatial patterning of the immigrant self-employment rates is significant for each definition of proximity, with neighbouring units that are likely to exhibit similar rates. On the other hand, the magnitude of the estimated global spatial autocorrelation is low (Griffith 2003). By changing the number of neighbours considered for each local unit, we can see that the resulting $p$-value decreases consistently the more neighbours we account for, while Moran's $I$ follows a nonlinear pattern reaching a peek first, and then starting to fall (see Table 5). This occurs roughly when the spatial weights matrix accounts on average for more than two and less than five neighbours per spatial unit, suggesting that the observed spatial patterns are bounded within the immediately adjacent municipalities.

9 Moran's $I$ is the most commonly used statistical indicator for spatial autocorrelation. It is essentially a modified correlation index, and is calculated as:

$$
I=\frac{N \sum_{i} \sum_{j} w_{i j}\left(x_{i}-\bar{x}\right)\left(x_{j}-\bar{x}\right)}{\left(\sum_{i} \sum_{j} w_{i j}\right) \sum_{i}\left(x_{i}-\bar{x}\right)^{2}},
$$

where, for $N$ regions, $x_{i}$ represents the value taken by the generic variable $x$ in unit $i$, and $w_{i j}$ is the value of the $(i, j)$ cell oaf a spatial weights matrix $W$, suitably coded to indicate the spatial relationship between each pair of regions $i$ and $j$.

10 The $k$-nearest neighbours definition of proximity considers the geographical centroid of each local unit, and selects as neighbours the units which have the closest $k$ centroids. Distance threshold neighbours are selected similarly, using as the only criterion a suitably selected maximum distance between centroids. Neighbours defined according to the queen definition of contiguity share a common border. Differently from the rook contiguity case, queen contiguity also allows the length of the common border to be zero (as it would be for diagonal neighbours in a chessboard grid).

11 Travel time data were computed for the year 2005, considering travel by car in minutes for a network that: (1) considers no other road users; and (2) considers other road users based on the capacity-restrain-function (ARE, 2010). The zones are based on the 2000 definition of the Swiss Federal Office for Statistics (municipalities). 
Table 5. Moran's I values for immigrant self-employment rates by definition of proximity

\begin{tabular}{|c|c|c|c|c|c|c|c|c|c|c|c|c|c|c|c|}
\hline & $\begin{array}{l}\mathrm{KNN} \\
(k=1)\end{array}$ & $\begin{array}{l}\mathrm{KNN} \\
(k=2)\end{array}$ & $\begin{array}{l}\mathrm{KNN} \\
(k=3)\end{array}$ & $\begin{array}{l}\text { Queen } \\
1 \text { st } \\
\text { order }\end{array}$ & $\begin{array}{l}\text { Queen } \\
\text { 2nd } \\
\text { order }\end{array}$ & $\begin{array}{l}\text { Queen } \\
\text { 3rd } \\
\text { order }\end{array}$ & $\begin{array}{l}\text { Distance } \\
\text { thresh. }\end{array}$ & $\begin{array}{l}\text { Distance } \\
\text { thresh. }{ }^{*} \\
1.5\end{array}$ & $\begin{array}{l}\text { Distance } \\
\text { thresh. } * 2\end{array}$ & $\begin{array}{l}\text { Travel } \\
\text { time (cut- } \\
\text { off }=5 \\
\text { min) } 1\end{array}$ & $\begin{array}{l}\text { Travel } \\
\text { time (cut- } \\
\text { off }=15 \\
\text { min })^{2}\end{array}$ & $\begin{array}{l}\text { Travel } \\
\text { time (cut- } \\
\text { off }=31 \\
\text { min) }\end{array}$ & $\begin{array}{l}\text { Cong. } \\
\text { travel time } \\
\text { (cut-off }=5 \\
\text { min) }{ }^{3}\end{array}$ & $\begin{array}{l}\text { Cong. } \\
\text { travel time } \\
\text { (cut-off }= \\
15 \mathrm{~min})^{4}\end{array}$ & $\begin{array}{l}\text { Cong. } \\
\text { travel time } \\
\text { (cut-off = } \\
36 \mathrm{~min} \text { ) }\end{array}$ \\
\hline Moran's $I$ & 0.090 & 0.112 & 0.120 & 0.111 & 0.095 & 0.094 & 0.101 & 0.095 & 0.090 & 0.080 & 0.083 & 0.072 & 0.077 & 0.081 & 0.067 \\
\hline$p$-value & 0.000 & 0.000 & 0.000 & 0.000 & 0.000 & 0.000 & 0.000 & 0.000 & 0.000 & 0.000 & 0.000 & 0.000 & 0.000 & 0.000 & 0.000 \\
\hline $\begin{array}{l}\text { Mean no. } \\
\text { of links }\end{array}$ & 1 & 2 & 3 & 5.2 & 17.1 & 36.4 & 40.6 & 83.5 & 137.5 & 1.9 & 34.0 & 175.3 & 1.8 & 31.3 & 222.5 \\
\hline
\end{tabular}

${ }^{1} 786$ regions with no links; ${ }^{2} 8$ regions with no links; ${ }^{3} 837$ regions with no links; ${ }^{4} 8$ regions with no links.

Notes: KNN $(k=k)=k$-nearest neighbours; Queen $a$ th order $=$ queen definition of contiguity of order $a$; distance thresh. * $b=$ distance threshold equal to max distance of KNN $(k=1) *$ the factor $b$; (cong.) travel time (cut-off $=c$ min) $=$ neighbours based on a (congested) travel time threshold of $c$ minutes. 
If we account for neighbours according to travel time (under both hypotheses of congestion and no congestion), Moran's I values are somehow lower with a comparable number of neighbours (e.g., two-nearest neighbours and travel times neighbours with a cut-off of 5 minutes). However, it should be noted that the results for the first two cut-offs (5 and $15 \mathrm{~min}$ ) do exclude some observations (which are left with no neighbours because they are too distant from any other unit). If we consider the congestion hypothesis, the measure of global autocorrelation is even lower.

For illustrative purposes, we report, in Figure 4, correlograms for the first 15 orders of the $k$ nearest- and queen-contiguity-based neighbours definitions, while the correlogram for the distance thresholds covers all ranges (to a maximum of $360 \mathrm{~km}$ ). In Figure $4 \mathrm{a}$, Moran's $I$ estimates for the $k$ nearest neighbours are plotted for every $k=1, \ldots, 15$ (each point adds an additional neighbour). All indices identify statistically significant spatial autocorrelation. The largest Moran's $I$ is reported for $k=3$. Thus, this definition is suggested to capture the largest degree of spatial dependence in our dependent variable. In Figure $4 b$, a comparable graph is reported for the queen contiguity neighbours, with appropriate confidence intervals (each point represents an additional order of contiguous neighbours that are taken into consideration). All the orders of contiguity are significant but the last, although $p$-values should be adjusted for comparative reasons (Bivand et al. 2008, pp. 267-8). The correlogram in Figure 4c shows the significant (bigger dots) and non-significant values of Moran's $I$ by distance bands. In this case, significant global spatial autocorrelation is detected below a coordinate range of 60,000 from each local unit, which corresponds, in the Swiss coordinates system, to a great-circle range of $60 \mathrm{~km}$ (metric system). There are, however, two additional distance bands for which Moran's $I$ is again significant, corresponding to roughly $280 \mathrm{~km}$ and $320 \mathrm{~km}$, but the range is far beyond our interest, and most likely captures similarities between the French- and Italian-speaking regions.

(a)

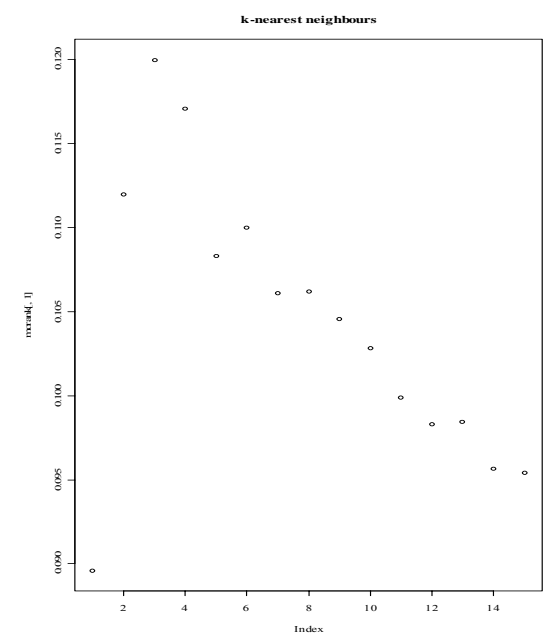

(b)

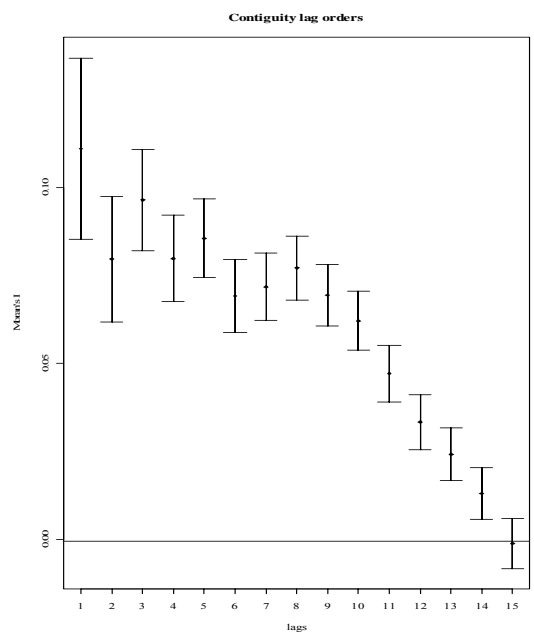

(c)

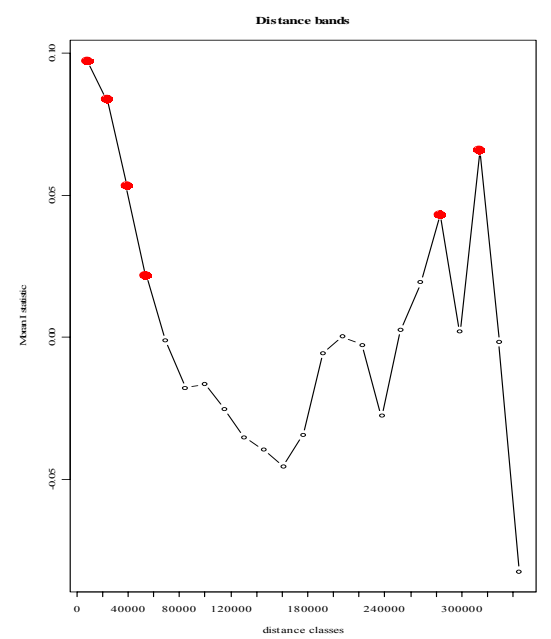

Figure 4. Correlograms for lags by neighbouring definitions: (a) $k$-nearest neighbours; (b) rook contiguity; (c) distance thresholds.

Although there is no overall consensus that models explaining the determinants of immigrant self-employment may reveal spatial dependence (with the only exception, at our best knowledge, of a regional analysis of Brazilian natives' entrepreneurship rates; Moro et al. 2003), we find evidence of spatial clustering in our data. The magnitude of global autocorrelation is small, but still not correcting for spatial dependence can lead to model misspecification resulting in biased and/or inconsistent OLS estimates (Anselin 1988). Moreover, the results of tests for the presence of global autocorrelation using different definitions of proximity have highlighted patterns limited to the immediate surroundings, suggesting processes of contamination/imitation that are locally bounded. In fact, the effects of proximity decade after considering more than six neighbours in the $k$-nearest neighbours definition, or more than eight orders of contiguity. Using a distance matrix, Moran's $I$ 
decades as well when we account for neighbours within a range beyond $60 \mathrm{~km}$. Finally, we reestimate Model 3 using different the spatial weights matrices considered above.

Table 6 presents the results obtained for the urban/suburb data subsample. The consistent significance of the spatial dependence parameter $(\rho)$ in our spatial lag models is further support for our hypothesis of spatial network effects between immigrants, while with regard to size, the parameter estimate ranges from 0.08 and 0.25 . The parameter estimates for all other variables are highly stable.

The variation in $\rho$ is driven by the extent of the geographical range selected for the spatial weights matrix, as the parameter increases with the number of neighbours that are accounted for. Among the control and ecological variables, we find an opposite result: the parameter estimates for the share of men, for the share of employed in the third sector, and for age tend to slightly decrease in size the more neighbours are used. Such parameter attenuation is consistent with what is suggested by LeSage and Pace (2009), who point out that inference regarding impacts in a spatial autoregressive model should be taken with caution (with respect to the usual interpretation of OLS estimates), since the spatial lag model allows changes observed for an explanatory variable in local unit $i$ to affect the dependent variable both in unit $i$ and in other units $j(\neq i)$ defined as neighbours of $i$ in the spatial weights matrix used.

In Table 6, the only regression parameter that experiences a change in its significance level is the one for altitude (ZMIN). It is clear that the enlargement of the geographical area considered by the model will lead to comparisons between regions that are more far away from each other, and altitude comes into play, particularly in a country with wide elevation differences like Switzerland. The parameter for altitude becomes significant for the wider distance bands, and is positive, suggesting that, when the share of low- and high-elevation units are compared, it helps explaining the conditional share of self-employed. Our interpretation is that in more elevated municipalities employment opportunities are rare (and often subject to high seasonality, at least in skiing resorts), and therefore local immigrants tend to self-select themselves into entrepreneurial positions.

According to the AIC and log-likelihood values reported in the lower part of Table 6 , the model specification that shows the best fit - although within a framework of rather small variations from case to case - is the one accounting for neighbours within a distance range of 1.5 times the minimum distance $(11.7 \mathrm{~km})$ necessary in order for all local units to have at least one neighbour ('Distance thresh. * 1.5 ', which corresponds to $11.7 \mathrm{~km} * 1.5=17.6 \mathrm{~km}) .{ }^{12}$

Table 7 provides similar results obtained for the rural subsample of our data. Again, the results of Table 4 are confirmed for all spatial weights matrices, with rather robust findings. As above, the spatial dependence parameter $\rho$ is always significant, and increases with the geographical range of the neighbouring criteria. Residual spatial autocorrelation is non-significant in seven cases out of nine, when using contiguity-based spatial weight matrices, or after the inclusion of neighbours in a distance band of more than $11.7 \mathrm{~km}$, or when using $k$-nearest neighbours with $k>1$. Because this result is only found for the rural subsample, we conclude that urbanized areas 'hide' further unobserved variables and spatial interaction effects, for example due to urbanization (coreperiphery effects), which are instead not relevant at the rural level. Model fits improve when increasing the number of neighbours, and the model estimated using the widest distance band ('Distance thresh. * 1.5 ', corresponding to $23.4 \mathrm{~km}$ ) shows the best log-likelihood and AIC. Given the geographical size of rural municipalities, which are much wider than in the urban case, this result could have been expected. Nonetheless, it confirms that also in a rural context spatial interaction beyond city boundaries occurs, and it stretches to adapt to the geographical characteristics of the area.

12 The spatial lag specification does not seem to catch all residual autocorrelation, which remains significant for all estimations. A richer modelling specification, based on the so-called spatial Durbin approach, would be most likely to eliminate this further residual correlation. In this paper, we limit our analysis to the spatial lag specification, since our interest lies in the estimation of the spatial dependence parameter. 
Table 6. Regression results for the unpooled model, by neighbours definition (urban subsample)

\begin{tabular}{|c|c|c|c|c|c|c|c|c|c|}
\hline & $\begin{array}{l}\mathrm{KNN} \\
(k=1)\end{array}$ & $\begin{array}{l}\mathrm{KNN} \\
(k=2)\end{array}$ & $\begin{array}{l}\mathrm{KNN} \\
(k=3)\end{array}$ & $\begin{array}{l}\text { Queen } \\
1 \text { st } \\
\text { order }\end{array}$ & $\begin{array}{l}\text { Queen } \\
\text { 2nd } \\
\text { order }\end{array}$ & $\begin{array}{l}\text { Queen } \\
\text { 3rd } \\
\text { order }\end{array}$ & $\begin{array}{l}\text { Distance } \\
\text { thresh. }\end{array}$ & $\begin{array}{l}\text { Distance } \\
\text { thresh. } * 1.5\end{array}$ & $\begin{array}{l}\text { Distance } \\
\text { thresh. } * 2\end{array}$ \\
\hline \multicolumn{10}{|l|}{ Local ethnic characteristics } \\
\hline $\log$ (HERFINDAHL) & $\begin{array}{c}0.01 \\
(0.03)\end{array}$ & $\begin{array}{r}0.00 \\
(0.03)\end{array}$ & $\begin{array}{c}0.00 \\
(0.03)\end{array}$ & $\begin{array}{c}0.00 \\
(0.03)\end{array}$ & $\begin{array}{l}-0.01 \\
(0.03)\end{array}$ & $\begin{array}{l}-0.02 \\
(0.03)\end{array}$ & $\begin{array}{l}-0.01 \\
(0.03)\end{array}$ & $\begin{array}{l}-0.02 \\
(0.03)\end{array}$ & $\begin{array}{l}-0.01 \\
(0.03)\end{array}$ \\
\hline RECENTIMMIGR & $\begin{array}{l}-0.14 \\
(0.03)^{* * *}\end{array}$ & $\begin{array}{l}-0.14 \\
(0.03)^{* * *}\end{array}$ & $\begin{array}{l}-0.14 \\
(0.03)^{* * *}\end{array}$ & $\begin{array}{l}-0.14 \\
(0.03)^{* * *}\end{array}$ & $\begin{array}{l}-0.14 \\
(0.03)^{* * *}\end{array}$ & $\begin{array}{l}-0.14 \\
(0.03)^{* * *}\end{array}$ & $\begin{array}{l}-0.13 \\
(0.03)^{* * *}\end{array}$ & $\begin{array}{l}-0.14 \\
(0.03)^{* * *}\end{array}$ & $\begin{array}{l}-0.14 \\
(0.03)^{* * *}\end{array}$ \\
\hline LANGPROALL & $\begin{array}{l}0.14 \\
(0.04)^{* * *}\end{array}$ & $\begin{array}{l}0.14 \\
(0.04)^{* * *}\end{array}$ & $\begin{array}{l}0.13 \\
(0.04)^{* * *}\end{array}$ & $\begin{array}{l}0.13 \\
(0.04)^{* * *}\end{array}$ & $\begin{array}{l}0.13 \\
(0.04)^{* * *}\end{array}$ & $\begin{array}{l}0.13 \\
(0.04)^{* * *}\end{array}$ & $\begin{array}{l}0.13 \\
(0.04)^{* * *}\end{array}$ & $\begin{array}{l}0.13 \\
(0.04)^{* * *}\end{array}$ & $\begin{array}{l}0.12 \\
(0.04)^{* * *}\end{array}$ \\
\hline \multicolumn{10}{|l|}{ Controls } \\
\hline $\log ($ FORACTIVEMEN) & $\begin{array}{l}0.72 \\
(0.15)^{* * *}\end{array}$ & $\begin{array}{l}0.71 \\
(0.15)^{* * *}\end{array}$ & $\begin{array}{l}0.7 \\
(0.15)^{* * *}\end{array}$ & $\begin{array}{l}0.70 \\
(0.15)^{* * *}\end{array}$ & $\begin{array}{l}0.68 \\
(0.15)^{* * *}\end{array}$ & $\begin{array}{l}0.68 \\
(0.15)^{* * *}\end{array}$ & $\begin{array}{l}0.69 \\
(0.15)^{* * *}\end{array}$ & $\begin{array}{l}0.67 \\
(0.15)^{* * *}\end{array}$ & $\begin{array}{l}0.67 \\
(0.15)^{* * *}\end{array}$ \\
\hline log(FORACTIVEMARRIED) & $\begin{array}{c}0.02 \\
(0.14)\end{array}$ & $\begin{array}{r}0.04 \\
(0.14)\end{array}$ & $\begin{array}{c}0.03 \\
(0.14)\end{array}$ & $\begin{array}{c}0.03 \\
(0.14)\end{array}$ & $\begin{array}{c}0.03 \\
(0.14)\end{array}$ & $\begin{array}{c}0.01 \\
(0.14)\end{array}$ & $\begin{array}{c}0.02 \\
(0.14)\end{array}$ & $\begin{array}{c}0.03 \\
(0.14)\end{array}$ & $\begin{array}{c}0.03 \\
(0.14)\end{array}$ \\
\hline $\log ($ FORACTIVENON) & $\begin{array}{l}-0.04 \\
(0.01)^{* * *}\end{array}$ & $\begin{array}{l}-0.04 \\
(0.01)^{* * *}\end{array}$ & $\begin{array}{l}-0.04 \\
(0.01)^{* * *}\end{array}$ & $\begin{array}{l}-0.04 \\
(0.01)^{* * *}\end{array}$ & $\begin{array}{l}-0.04 \\
(0.01)^{* * *}\end{array}$ & $\begin{array}{l}-0.04 \\
(0.01)^{* * *}\end{array}$ & $\begin{array}{l}-0.04 \\
(0.01)^{* * *}\end{array}$ & $\begin{array}{l}-0.04 \\
(0.01)^{* * *}\end{array}$ & $\begin{array}{l}-0.04 \\
(0.01)^{* * *}\end{array}$ \\
\hline $\log ($ FOREMPTER) & $\begin{array}{l}0.25 \\
(0.07)^{* * *}\end{array}$ & $\begin{array}{l}0.24 \\
(0.07)^{* * *}\end{array}$ & $\begin{array}{l}0.24 \\
(0.07)^{* * *}\end{array}$ & $\begin{array}{l}0.24 \\
(0.07)^{* * *}\end{array}$ & $\begin{array}{l}0.22 \\
(0.07)^{* * *}\end{array}$ & $\begin{array}{l}0.21 \\
(0.07)^{* * *}\end{array}$ & $\begin{array}{l}0.23 \\
(0.07)^{* * *}\end{array}$ & $\begin{array}{l}0.21 \\
(0.07)^{* * *}\end{array}$ & $\begin{array}{l}0.21 \\
(0.07)^{* * *}\end{array}$ \\
\hline FORACTIVEAGE & $\begin{array}{l}2.80 \\
(0.56)^{* * *}\end{array}$ & $\begin{array}{l}2.76 \\
(0.56)^{* * *}\end{array}$ & $\begin{array}{l}2.68 \\
(0.56)^{* * *}\end{array}$ & $\begin{array}{l}2.71 \\
(0.56)^{* * *}\end{array}$ & $\begin{array}{l}2.60 \\
(0.56)^{* * *}\end{array}$ & $\begin{array}{l}2.54 \\
(0.57)^{* * *}\end{array}$ & $\begin{array}{l}2.59 \\
(0.56)^{* * *}\end{array}$ & $\begin{array}{l}2.53 \\
(0.57)^{* * *}\end{array}$ & $\begin{array}{l}2.55 \\
(0.56)^{* * *}\end{array}$ \\
\hline FORACTIVEAGE $* * 2$ & $\begin{array}{r}0.15 \\
(0.41)\end{array}$ & $\begin{array}{r}0.17 \\
(0.41)\end{array}$ & $\begin{array}{r}0.19 \\
(0.41)\end{array}$ & $\begin{array}{c}0.18 \\
(0.41)\end{array}$ & $\begin{array}{c}0.13 \\
(0.41)\end{array}$ & $\begin{array}{r}0.16 \\
(0.41)\end{array}$ & $\begin{array}{c}0.13 \\
(0.41)\end{array}$ & $\begin{array}{r}0.10 \\
(0.41)\end{array}$ & $\begin{array}{r}0.06 \\
(0.41)\end{array}$ \\
\hline $\log$ (FORACTIVECHIL) & $\begin{array}{l}-0.11 \\
(0.14)\end{array}$ & $\begin{array}{l}-0.12 \\
(0.14)\end{array}$ & $\begin{array}{l}-0.10 \\
(0.14)\end{array}$ & $\begin{array}{l}-0.11 \\
(0.14)\end{array}$ & $\begin{array}{l}-0.11 \\
(0.14)\end{array}$ & $\begin{array}{l}-0.09 \\
(0.14)\end{array}$ & $\begin{array}{l}-0.10 \\
(0.14)\end{array}$ & $\begin{array}{l}-0.11 \\
(0.14)\end{array}$ & $\begin{array}{l}-0.11 \\
(0.14)\end{array}$ \\
\hline log(FORACTIVEPROFEDU) & $\begin{array}{l}0.07 \\
(0.02)^{* * *}\end{array}$ & $\begin{array}{l}0.07 \\
(0.02)^{* * *}\end{array}$ & $\begin{array}{l}0.07 \\
(0.02)^{* * *}\end{array}$ & $\begin{array}{l}0.07 \\
(0.02)^{* * *}\end{array}$ & $\begin{array}{l}0.07 \\
(0.02)^{* * *}\end{array}$ & $\begin{array}{l}0.07 \\
(0.02)^{* * *}\end{array}$ & $\begin{array}{l}0.07 \\
(0.02)^{* * *}\end{array}$ & $\begin{array}{l}0.07 \\
(0.02)^{* * *}\end{array}$ & $\begin{array}{l}0.07 \\
(0.02)^{* * *}\end{array}$ \\
\hline $\log$ (FORACTIVEACCAEDU) & $\begin{array}{l}-0.02 \\
(0.01)\end{array}$ & $\begin{array}{l}-0.02 \\
(0.01)\end{array}$ & $\begin{array}{l}-0.02 \\
(0.01)\end{array}$ & $\begin{array}{l}-0.02 \\
(0.01)\end{array}$ & $\begin{array}{l}-0.02 \\
(0.01)\end{array}$ & $\begin{array}{l}-0.02 \\
(0.01)\end{array}$ & $\begin{array}{l}-0.02 \\
(0.01)\end{array}$ & $\begin{array}{l}-0.02 \\
(0.01)\end{array}$ & $\begin{array}{l}-0.02 \\
(0.01)\end{array}$ \\
\hline $\log (\mathrm{FORUNEMP})$ & $\begin{array}{l}-2.15 \\
(0.44)^{* * *}\end{array}$ & $\begin{array}{l}-2.08 \\
(0.44)^{* * *}\end{array}$ & $\begin{array}{l}-2.13 \\
(0.44)^{* * *}\end{array}$ & $\begin{array}{l}-2.07 \\
(0.44)^{* * *}\end{array}$ & $\begin{array}{l}-2.11 \\
(0.44)^{* * *}\end{array}$ & $\begin{array}{l}-2.16 \\
(0.44)^{* * *}\end{array}$ & $-2.15(0.44)^{* * *}$ & $\begin{array}{l}-2.18 \\
(0.44)^{* * *}\end{array}$ & $\begin{array}{l}-2.19 \\
(0.44)^{* * *}\end{array}$ \\
\hline $\log ($ FORUNEMP $) * * 2$ & $\begin{array}{c}0.58 \\
(0.43)\end{array}$ & $\begin{array}{r}0.60 \\
(0.43)\end{array}$ & $\begin{array}{c}0.62 \\
(0.43)\end{array}$ & $\begin{array}{c}0.61 \\
(0.43)\end{array}$ & $\begin{array}{c}0.68 \\
(0.43)\end{array}$ & $\begin{array}{r}0.66 \\
(0.43)\end{array}$ & $\begin{array}{r}0.57 \\
(0.43)\end{array}$ & $\begin{array}{c}0.64 \\
(0.43)\end{array}$ & $\begin{array}{c}0.65 \\
(0.43)\end{array}$ \\
\hline Local unit's characteristics & & & & & & & & & \\
\hline $\log (\mathrm{ZMIN})$ & $\begin{array}{c}0.03 \\
(0.05)\end{array}$ & $\begin{array}{c}0.04 \\
(0.05)\end{array}$ & $\begin{array}{c}0.04 \\
(0.05)\end{array}$ & $\begin{array}{c}0.05 \\
(0.05)\end{array}$ & $\begin{array}{c}0.06 \\
(0.05)\end{array}$ & $\begin{array}{c}0.08 \\
(0.05)\end{array}$ & $\begin{array}{r}0.07 \\
(0.05)\end{array}$ & $\begin{array}{l}0.10 \\
(0.05)^{* *}\end{array}$ & $\begin{array}{l}0.10 \\
(0.05)^{* *}\end{array}$ \\
\hline $\log ($ SWIEMPSE) & $\begin{array}{l}0.54 \\
(0.06)^{* * *}\end{array}$ & $\begin{array}{l}0.54 \\
(0.06)^{* * *}\end{array}$ & $\begin{array}{l}0.54 \\
(0.06)^{* * *}\end{array}$ & $\begin{array}{l}0.54 \\
(0.06)^{* * *}\end{array}$ & $\begin{array}{l}0.53 \\
(0.06)^{* * *}\end{array}$ & $\begin{array}{l}0.54 \\
(0.06)^{* * *}\end{array}$ & $\begin{array}{l}0.54 \\
(0.06)^{* * *}\end{array}$ & $\begin{array}{l}0.54 \\
(0.06)^{* * *}\end{array}$ & $\begin{array}{l}0.54 \\
(0.06)^{* * *}\end{array}$ \\
\hline$P$ & $\begin{array}{l}0.08 \\
(0.02)^{* * *}\end{array}$ & $\begin{array}{l}0.09 \\
(0.03)^{* * *}\end{array}$ & $\begin{array}{l}0.12 \\
(0.03 * * *\end{array}$ & $\begin{array}{l}0.11 \\
(0.03)^{* * *}\end{array}$ & $\begin{array}{l}0.17 \\
(0.04)^{* * *}\end{array}$ & $\begin{array}{l}0.22 \\
(0.05)^{* * *}\end{array}$ & $\begin{array}{l}0.18 \\
(0.04)^{* * *}\end{array}$ & $\begin{array}{l}0.25 \\
(0.05)^{* * *}\end{array}$ & $\begin{array}{l}0.25 \\
(0.05)^{* * *}\end{array}$ \\
\hline
\end{tabular}




\begin{tabular}{|c|c|c|c|c|c|c|c|c|c|}
\hline & $\begin{array}{l}\text { KNN } \\
(k=1)\end{array}$ & $\begin{array}{l}\mathrm{KNN} \\
(k=2)\end{array}$ & $\begin{array}{l}\text { KNN } \\
(k=3)\end{array}$ & $\begin{array}{l}\text { Queen } \\
1 \text { st } \\
\text { order }\end{array}$ & $\begin{array}{l}\text { Queen } \\
\text { 2nd } \\
\text { order }\end{array}$ & $\begin{array}{l}\text { Queen } \\
\text { 3rd } \\
\text { order }\end{array}$ & $\begin{array}{l}\text { Distance } \\
\text { thresh. }\end{array}$ & $\begin{array}{l}\text { Distance } \\
\text { thresh. * } 1.5\end{array}$ & $\begin{array}{l}\text { Distance } \\
\text { thresh. } * 2\end{array}$ \\
\hline Intercept & $\begin{array}{l}5.45 \\
(0.41)^{* * *}\end{array}$ & $\begin{array}{l}5.39 \\
(0.43)^{* * *}\end{array}$ & $\begin{array}{c}5.22 \\
(0.44)^{* * *}\end{array}$ & $\begin{array}{l}5.19 \\
(0.43)^{* * *}\end{array}$ & $\begin{array}{c}4.84 \\
(0.46)^{* * *}\end{array}$ & $\begin{array}{l}4.5 \\
(0.51)^{* * *}\end{array}$ & $\begin{array}{c}4.72 \\
(0.48)^{* * *} \\
\end{array}$ & $\begin{array}{c}4.25 \\
(0.5)^{* * *} \\
\end{array}$ & $\begin{array}{c}4.24 \\
(0.51)^{* * *}\end{array}$ \\
\hline Log-likelihood & -467.26 & -468.88 & -466.75 & -465.26 & -463.17 & 464.59 & -464.28 & -461.99 & -462.86 \\
\hline ML residual standard deviation $(\sigma)$ & 0.39 & 0.39 & 0.39 & 0.39 & 0.39 & 0.39 & 0.39 & 0.39 & 0.39 \\
\hline AIC & 972.53 & 975.76 & 971.51 & 968.52 & 964.35 & 967.18 & 966.56 & 961.98 & 963.73 \\
\hline LM test for res. sp. autocorr. & $2.88 *$ & $9.54 * * *$ & $11.73 * * *$ & $9.75 * * *$ & $31.02 * * *$ & $27.57 * * *$ & $29.08 * * *$ & $56.26 * * *$ & $72.99 * * *$ \\
\hline
\end{tabular}

$* * *, * *$ and $*$ denote significance at the 1,5 and 10 per cent levels.

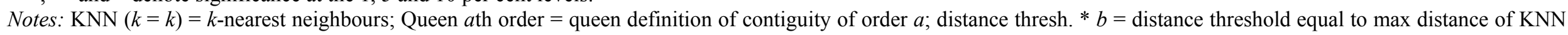
$(k=1) *$ the factor $b$.

Table 7. Regression results for the unpooled model, by neighbours definition (rural subsample)

\begin{tabular}{|c|c|c|c|c|c|c|c|c|c|}
\hline & $\begin{array}{l}\text { KNN } \\
(k=1)\end{array}$ & $\begin{array}{l}\mathrm{KNN} \\
(k=2)\end{array}$ & $\begin{array}{l}\text { KNN } \\
(k=3)\end{array}$ & $\begin{array}{l}\text { Queen } \\
1 \mathrm{st} \\
\text { order }\end{array}$ & $\begin{array}{l}\text { Queen } \\
\text { 2nd } \\
\text { order }\end{array}$ & $\begin{array}{l}\text { Queen } \\
\text { 3rd } \\
\text { order }\end{array}$ & $\begin{array}{l}\text { Distance } \\
\text { thresh. }\end{array}$ & $\begin{array}{l}\text { Distance } \\
\text { thresh. } * 1.5\end{array}$ & $\begin{array}{l}\text { Distance } \\
\text { thresh. } * 2\end{array}$ \\
\hline \multicolumn{10}{|l|}{ Local ethnic characteristics } \\
\hline $\log ($ HERFINDAHL) & $\begin{array}{l}-0.08 \\
(0.03)^{* *}\end{array}$ & $\begin{array}{l}-0.08 \\
(0.03)^{* * *}\end{array}$ & $\begin{array}{l}-0.08 \\
(0.03)^{* * *}\end{array}$ & $\begin{array}{l}-0.09 \\
(0.03)^{* * *}\end{array}$ & $\begin{array}{l}-0.09 \\
(0.03)^{* * *}\end{array}$ & $\begin{array}{l}-0.09 \\
(0.03)^{* * *}\end{array}$ & $\begin{array}{l}-0.09 \\
(0.03)^{* * *}\end{array}$ & $\begin{array}{l}-0.10 \\
(0.03)^{* * *}\end{array}$ & $\begin{array}{l}-0.10 \\
(0.03)^{* * *}\end{array}$ \\
\hline RECENTIMMIGR & $\begin{array}{l}-0.16 \\
(0.05)^{* * *}\end{array}$ & $\begin{array}{l}-0.16 \\
(0.05)^{* * *}\end{array}$ & $\begin{array}{l}-0.16 \\
(0.05)^{* * *}\end{array}$ & $\begin{array}{l}-0.17 \\
(0.05)^{* * *}\end{array}$ & $\begin{array}{l}-0.16 \\
(0.05)^{* * *}\end{array}$ & $\begin{array}{l}-0.15 \\
(0.05)^{* * *}\end{array}$ & $\begin{array}{l}-0.15 \\
(0.05)^{* * *}\end{array}$ & $\begin{array}{l}-0.15 \\
(0.05)^{* * *}\end{array}$ & $\begin{array}{l}-0.14 \\
(0.05)^{* * *}\end{array}$ \\
\hline LANGPROALL & $\begin{array}{l}0.23 \\
(0.05)^{* * *}\end{array}$ & $\begin{array}{l}0.22 \\
(0.05)^{* * *}\end{array}$ & $\begin{array}{l}0.22 \\
(0.05)^{* * *}\end{array}$ & $\begin{array}{l}0.23 \\
(0.05)^{* * *}\end{array}$ & $\begin{array}{l}0.23 \\
(0.05)^{* * *}\end{array}$ & $\begin{array}{l}0.22 \\
(0.05)^{* * *}\end{array}$ & $\begin{array}{l}0.22 \\
(0.05)^{* * *}\end{array}$ & $\begin{array}{c}0.21 \\
(0.05)^{* * *}\end{array}$ & $\begin{array}{l}0.21 \\
(0.05)^{* * *}\end{array}$ \\
\hline \multicolumn{10}{|l|}{ Controls } \\
\hline $\log ($ FORACTIVEMEN) & $\begin{array}{l}-0.04 \\
(0.08)\end{array}$ & $\begin{array}{l}-0.04 \\
(0.08)\end{array}$ & $\begin{array}{l}-0.05 \\
(0.08)\end{array}$ & $\begin{array}{l}-0.03 \\
(0.08)\end{array}$ & $\begin{array}{l}-0.04 \\
(0.08)\end{array}$ & $\begin{array}{l}-0.04 \\
(0.08)\end{array}$ & $\begin{array}{l}-0.05 \\
(0.08)\end{array}$ & $\begin{array}{l}-0.05 \\
(0.08)\end{array}$ & $\begin{array}{l}-0.06 \\
(0.08)\end{array}$ \\
\hline $\log$ (FORACTIVEMARRIED) & $\begin{array}{l}-0.04 \\
(0.05)\end{array}$ & $\begin{array}{l}-0.05 \\
(0.05)\end{array}$ & $\begin{array}{l}-0.05 \\
(0.05)\end{array}$ & $\begin{array}{l}-0.05 \\
(0.05)\end{array}$ & $\begin{array}{l}-0.06 \\
(0.05)\end{array}$ & $\begin{array}{l}-0.05 \\
(0.05)\end{array}$ & $\begin{array}{l}-0.05 \\
(0.05)\end{array}$ & $\begin{array}{l}-0.05 \\
(0.05)\end{array}$ & $\begin{array}{l}-0.05 \\
(0.05)\end{array}$ \\
\hline $\log ($ FORACTIVENON) & $\begin{array}{l}-0.04 \\
(0.01)^{* * *}\end{array}$ & $\begin{array}{l}-0.04 \\
(0.01)^{* * *}\end{array}$ & $\begin{array}{l}-0.04 \\
(0.01)^{* * *}\end{array}$ & $\begin{array}{l}-0.04 \\
(0.01)^{* * *}\end{array}$ & $\begin{array}{l}-0.04 \\
(0.01)^{* * *}\end{array}$ & $\begin{array}{l}-0.04 \\
(0.01)^{* * *}\end{array}$ & $\begin{array}{l}-0.04 \\
(0.01)^{* * *}\end{array}$ & $\begin{array}{l}-0.04 \\
(0.01)^{* * *}\end{array}$ & $\begin{array}{l}-0.04 \\
(0.01)^{* * *}\end{array}$ \\
\hline $\log$ (FOREMPTER) & $\begin{array}{c}0.04 \\
(0.02)^{*}\end{array}$ & $\begin{array}{c}0.03 \\
(0.02)^{*}\end{array}$ & $\begin{array}{c}0.04 \\
(0.02)^{*}\end{array}$ & $\begin{array}{c}0.04 \\
(0.02)^{*}\end{array}$ & $\begin{array}{c}0.04 \\
(0.02)^{*}\end{array}$ & $\begin{array}{c}0.04 \\
(0.02)^{*}\end{array}$ & $\begin{array}{c}0.03 \\
(0.02)^{*}\end{array}$ & $\begin{array}{c}0.03 \\
(0.02)^{*}\end{array}$ & $\begin{array}{c}0.03 \\
(0.02)^{*}\end{array}$ \\
\hline FORACTIVEAGE & $\begin{array}{l}3.80 \\
(0.66)^{* * *}\end{array}$ & $\begin{array}{l}3.77 \\
(0.66)^{* * *}\end{array}$ & $\begin{array}{l}3.76 \\
(0.66)^{* * *}\end{array}$ & $\begin{array}{l}3.81 \\
(0.67)^{* * *}\end{array}$ & $\begin{array}{l}3.83 \\
(0.66)^{* * *}\end{array}$ & $\begin{array}{l}3.81 \\
(0.66)^{* * *}\end{array}$ & $\begin{array}{l}3.81 \\
(0.66)^{* * *}\end{array}$ & $\begin{array}{l}3.80 \\
(0.66)^{* * *}\end{array}$ & $\begin{array}{l}3.71 \\
(0.66)^{* * *}\end{array}$ \\
\hline FORACTIVEAGE $* * 2$ & $\begin{array}{l}1.44 \\
(0.63)^{* *}\end{array}$ & $\begin{array}{l}1.57 \\
(0.63)^{* *}\end{array}$ & $\begin{array}{c}1.53 \\
(0.63)^{* *}\end{array}$ & $\begin{array}{l}1.53 \\
(0.64)^{* *}\end{array}$ & $\begin{array}{l}1.52 \\
(0.63)^{* *}\end{array}$ & $\begin{array}{c}1.48 \\
(0.63)^{* *}\end{array}$ & $\begin{array}{c}1.51 \\
(0.63)^{* *}\end{array}$ & $\begin{array}{c}1.48 \\
(0.62)^{* *}\end{array}$ & $\begin{array}{l}1.49 \\
(0.62)^{* *}\end{array}$ \\
\hline $\log$ (FORACTIVECHIL) & $\begin{array}{l}-0.42 \\
(0.09)^{* * *}\end{array}$ & $\begin{array}{l}-0.41 \\
(0.09)^{* * *}\end{array}$ & $\begin{array}{l}-0.40 \\
(0.09)^{* * *}\end{array}$ & $\begin{array}{l}-0.43 \\
(0.09)^{* * *}\end{array}$ & $\begin{array}{l}-0.41 \\
(0.09)^{* * *}\end{array}$ & $\begin{array}{l}-0.37 \\
(0.09)^{* * *}\end{array}$ & $\begin{array}{l}-0.37 \\
(0.09)^{* * *}\end{array}$ & $\begin{array}{l}-0.35 \\
(0.09)^{* * *}\end{array}$ & $\begin{array}{l}-0.35 \\
(0.09)^{* * *}\end{array}$ \\
\hline
\end{tabular}




\begin{tabular}{|c|c|c|c|c|c|c|c|c|c|}
\hline & $\begin{array}{l}\text { KNN } \\
(k=1)\end{array}$ & $\begin{array}{l}\mathrm{KNN} \\
(k=2)\end{array}$ & $\begin{array}{l}\mathrm{KNN} \\
(k=3)\end{array}$ & $\begin{array}{l}\text { Queen } \\
1 \text { st } \\
\text { order }\end{array}$ & $\begin{array}{l}\text { Queen } \\
\text { 2nd } \\
\text { order }\end{array}$ & $\begin{array}{l}\text { Queen } \\
\text { 3rd } \\
\text { order }\end{array}$ & $\begin{array}{l}\text { Distance } \\
\text { thresh. }\end{array}$ & $\begin{array}{l}\text { Distance } \\
\text { thresh. } * 1.5\end{array}$ & $\begin{array}{l}\text { Distance } \\
\text { thresh. } * 2\end{array}$ \\
\hline $\log$ (FORACTIVEPROFEDU) & $\begin{array}{l}-0.03 \\
(0.01)^{* * *}\end{array}$ & $\begin{array}{l}-0.03 \\
(0.01)^{* * *}\end{array}$ & $\begin{array}{l}-0.03 \\
(0.01)^{* * *}\end{array}$ & $\begin{array}{l}-0.03 \\
(0.01)^{* * *}\end{array}$ & $\begin{array}{l}-0.03 \\
(0.01)^{* * *}\end{array}$ & $\begin{array}{l}-0.03 \\
(0.01)^{* * *}\end{array}$ & $\begin{array}{l}-0.03 \\
(0.01)^{* * *}\end{array}$ & $\begin{array}{l}-0.03 \\
(0.01)^{* * *}\end{array}$ & $\begin{array}{l}-0.03 \\
(0.01)^{* * *}\end{array}$ \\
\hline $\log$ (FORACTIVEACCAEDU) & $\begin{array}{l}-0.01 \\
(0.01)^{* *}\end{array}$ & $\begin{array}{l}-0.01 \\
(0.01)^{* *}\end{array}$ & $\begin{array}{l}-0.01 \\
(0.01)^{* *}\end{array}$ & $\begin{array}{l}-0.01 \\
(0.01)^{* *}\end{array}$ & $\begin{array}{l}-0.01 \\
(0.01)^{* *}\end{array}$ & $\begin{array}{l}-0.01 \\
(0.01)^{* *}\end{array}$ & $\begin{array}{l}-0.01 \\
(0.01)^{* *}\end{array}$ & $\begin{array}{l}-0.01 \\
(0.01)^{* *}\end{array}$ & $\begin{array}{l}-0.01 \\
(0.01)^{* *}\end{array}$ \\
\hline $\log (\mathrm{FORUNEMP})$ & $\begin{array}{l}-5.80 \\
(0.64)^{* * *}\end{array}$ & $\begin{array}{l}-5.79 \\
(0.65)^{* * *}\end{array}$ & $\begin{array}{l}-5.78 \\
(0.64)^{* * *}\end{array}$ & $\begin{array}{l}-5.98 \\
(0.65)^{* * *}\end{array}$ & $\begin{array}{l}-5.94 \\
(0.65)^{* * *}\end{array}$ & $\begin{array}{l}-5.86 \\
(0.65)^{* * *}\end{array}$ & $\begin{array}{l}-5.92 \\
(0.64)^{* * *}\end{array}$ & $\begin{array}{l}-5.87 \\
(0.64)^{* * *}\end{array}$ & $\begin{array}{l}-5.89 \\
(0.64)^{* * *}\end{array}$ \\
\hline $\log ($ FORUNEMP) $* * 2$ & $\begin{array}{l}6.26 \\
(0.63)^{* * *}\end{array}$ & $\begin{array}{l}6.26 \\
(0.63)^{* * *}\end{array}$ & $\begin{array}{l}6.25 \\
(0.63)^{* * *}\end{array}$ & $\begin{array}{l}6.31 \\
(0.64)^{* * *}\end{array}$ & $\begin{array}{l}6.26 \\
(0.64)^{* * *}\end{array}$ & $\begin{array}{l}6.36 \\
(0.63)^{* * *}\end{array}$ & $\begin{array}{l}6.33 \\
(0.63)^{* * *}\end{array}$ & $\begin{array}{l}6.40 \\
(0.63)^{* * *}\end{array}$ & $\begin{array}{l}6.39 \\
(0.63)^{* * *}\end{array}$ \\
\hline Local unit's characteristics & & & & & & & & & \\
\hline $\log (\mathrm{ZMIN})$ & $\begin{array}{c}0.05 \\
(0.05)\end{array}$ & $\begin{array}{c}0.05 \\
(0.05)\end{array}$ & $\begin{array}{c}0.05 \\
(0.05)\end{array}$ & $\begin{array}{c}0.06 \\
(0.05)\end{array}$ & $\begin{array}{c}0.05 \\
(0.05)\end{array}$ & $\begin{array}{c}0.06 \\
(0.05)\end{array}$ & $\begin{array}{c}0.06 \\
(0.05)\end{array}$ & $\begin{array}{c}0.06 \\
(0.05)\end{array}$ & $\begin{array}{c}0.05 \\
(0.05)\end{array}$ \\
\hline $\log ($ SWIEMPSE) & $\begin{array}{l}0.35 \\
(0.04)^{* * *}\end{array}$ & $\begin{array}{l}0.36 \\
(0.04)^{* * *}\end{array}$ & $\begin{array}{l}0.36 \\
(0.04)^{* * *}\end{array}$ & $\begin{array}{l}0.36 \\
(0.04)^{* * *}\end{array}$ & $\begin{array}{l}0.36 \\
(0.04)^{* * *}\end{array}$ & $\begin{array}{l}0.35 \\
(0.04)^{* * *}\end{array}$ & $\begin{array}{l}0.35 \\
(0.04)^{* * *}\end{array}$ & $\begin{array}{l}0.35 \\
(0.04)^{* * *}\end{array}$ & $\begin{array}{l}0.35 \\
(0.04)^{* * *}\end{array}$ \\
\hline$\rho$ & $\begin{array}{c}0.11 \\
(0.02)^{* * *}\end{array}$ & $\begin{array}{c}0.13 \\
(0.02)^{* * * *}\end{array}$ & $\begin{array}{l}0.16 \\
(0.03)^{* * *}\end{array}$ & $\begin{array}{l}0.07 \\
(0.02)^{* * *}\end{array}$ & $\begin{array}{l}0.16 \\
(0.04)^{* * *}\end{array}$ & $\begin{array}{l}0.26 \\
(0.04)^{* * *}\end{array}$ & $\begin{array}{l}0.26 \\
(0.04)^{* * *}\end{array}$ & $\begin{array}{c}0.34 \\
(0.05)^{* * *}\end{array}$ & $\begin{array}{l}0.38 \\
(0.05)^{* * *}\end{array}$ \\
\hline Intercept & $\begin{array}{c}4.38 \\
(0.38)^{* * *}\end{array}$ & $\begin{array}{c}4.27 \\
(0.38)^{* * *}\end{array}$ & $\begin{array}{l}4.09 \\
(0.38)^{* * *}\end{array}$ & $\begin{array}{c}4.54 \\
(0.38)^{* * *}\end{array}$ & $\begin{array}{c}4.09 \\
(0.4)^{* * *}\end{array}$ & $\begin{array}{l}3.6 \\
(0.42)^{* * *}\end{array}$ & $\begin{array}{l}3.58 \\
(0.41)^{* * *}\end{array}$ & $\begin{array}{c}3.19 \\
(0.42)^{* * *}\end{array}$ & $\begin{array}{l}3.03 \\
(0.42)^{* * *}\end{array}$ \\
\hline Log-likelihood & $-1,327.60$ & $-1,331.43$ & $-1,327.53$ & $-1,342.96$ & $-1,337.35$ & $-1,329.53$ & $-1,326.33$ & $-1,319.97$ & $-1,319.02$ \\
\hline ML residual standard deviation $(\sigma)$ & 0.57 & 0.57 & 0.57 & 0.57 & 0.58 & 0.57 & 0.57 & 0.57 & 0.57 \\
\hline AIC & $2,693.20$ & $2,700.86$ & $2,693.07$ & $2,723.92$ & $2,712.71$ & $2,697.07$ & $2,690.67$ & $2,677.94$ & $2,676.05$ \\
\hline LM test for res. sp. autocorr. & $5.30 * *$ & 4.01 & 2.57 & 1.06 & 0.82 & 1.49 & $4.65 * *$ & 0.06 & 1.14 \\
\hline
\end{tabular}

$* * *, * *$ and $*$ denote significance at the 1,5 and 10 per cent levels.

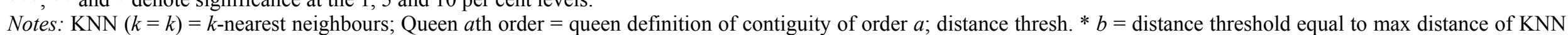
$(k=1) *$ the factor $b$. 


\section{Conclusions}

This paper presented a series of statistical analyses aimed at investigating the determinants of immigrant self-employment rates in Switzerland. Unlike in many other countries, in Switzerland immigrants show a considerably lower propensity towards entrepreneurship compared to the natives, while they represent a high share of the total labour force.

Using Census data collected in the year 2000 and available at a high level of geographical disaggregation (our unit of analysis is the municipality), we focused on the exploration of local and spatial effects of imitation. We accounted for the presence of local role models by including in our model the self-employment rates of the natives. These are expected to capture network effects due to interaction with existing entrepreneurs (native entrepreneurs may act as potential role models for immigrants), as well as, from an econometric viewpoint, all unobservable factors that influence both natives and immigrants. Spatial network effects were captured by means of a spatial econometric approach which allowed us to consider the self-employment rates of immigrants living in adjacent communities (interaction with other immigrants is expected to increase the available set of information and to provide successful entrepreneurial examples).

The empirical results obtained for our model suggest that, in addition to the control variables typical of the self-employment literature, the self-employment rates of immigrants are positively related to the ones displayed (locally) by the natives, with a strongly significant regression parameter. Furthermore, we found a significant and positive effect of the self-employment choices of immigrants living in neighbouring communities, identified by a spatial dependence parameter. We stress that our identification strategy, including the characteristics of the immigrant pool, controls for geography and other local aspects, and the natives' rates, allows us to interpret the spatial dependence parameter as an indicator of spatial spillovers and knowledge exchange within the immigrant population of wider areas.

Robustness analyses controlling for the different features of urbanized and rural municipalities show differences in the set of skills and characteristics required for self-employment choices. Finally, a spatial sensitivity analysis showed that our findings are consistent over different assumptions on the nature of spatial interaction. However, spatial spillover effects are locally bounded and disappear beyond a range of about $60 \mathrm{~km}$.

Future developments on this topic should ideally focus on georeferenced microdata, which would allow the analyst to pinpoint more accurately imitation effects and spillovers due to knowledge exchange. Additionally, panel data could be a valuable source of information for studying the dynamic processes towards self-employment.

\section{References}

Acs Z.J. and L. Preston (1997) Small and Medium-Sized Enterprises, Technology, and Globalization: Introduction to a Special Issue on Small and Medium-Sized Enterprises in the Global Economy. Small Business Economics 9 (1), 1-6

Aldrich H. and C. Zimmer (1986) Entrepreneurship through Social Networks. In D.L. Sexton and R.W. Smilor (eds), The Art and Science of Entrepreneurship. Ballinger: Cambridge, pp. 3-24

Alesina A. and E. La Ferrara (2002) Who Trusts Others? Journal of Public Economics 85 (2), 207-34

Alesina A. and E. La Ferrara (2005) Ethnic Diversity and Economic Performance. Journal of Economic Literature 43 (3), 762-800

Anselin L. (1988) Spatial Econometrics: Methods and Models. Kluwer Academic Publishers: Dordrecht Boston

Anselin L. (1998) Exploratory Spatial Data Analysis in a Geocomputational Environment. In P.A. Longley, S.M. Brooks, R. McDonnell and W. MacMillan (eds), Geocomputation: A Primer. Wiley: Chichester New York 
Anselin L. (1999) Interactive Techniques and Exploratory Spatial Data Analysis. In P.A. Longley, M.F. Goodchild, D.J. Maguire and D.W. Rhind (eds), Geographical Information Systems: Principles, Techniques, Applications, and Management. John Wiley: New York Chichester, pp. 251-64

Bailey T.C. and A.C. Gatrell (1995) Interactive Spatial Data Analysis. J. Wiley: New York

Bivand R.S., E.J. Pebesma and V. Gómez-Rubio (2008) Applied Spatial Data Analysis with R. Springer: New York London

Blanchflower D.G. and A.J. Oswald (1990) Self-Employment and the Enterprise Culture. In R. Jowell, S. Witherspoon and R. Jowell (eds), British Social Attitudes: The 7th Report. Gower Press: Aldershot, pp. 127-44

Blanchflower D.G. and A.J. Oswald (1991) Does Access to Capital Help Make an Entrepreneur? (NBER Working Paper No. 3252 (revised version)). Cambridge: National Bureau of Economic Research

Blau D.M. (1987) A Time-Series Analysis of Self-Employment in the United States. The Journal of Political Economy 95 (3), 445-67

Boden R.J. (1996) Gender and Self-Employment Selection: An Empirical Assessment. Journal of SocioEconomics 25 (6), 671-82

Boden R.J. (1999) Flexible Working Hours, Family Responsibilities, and Female Self-Employment. American Journal of Economics and Sociology 58 (1), 71-83

Borjas G.J. (1986) The Self-Employment Experience of Immigrants. The Journal of Human Resources 21 (4), 485-506

Bruce D. (1999) Do Husbands Matter? Married Women Entering Self-Employment. Small Business Economics 13 (4), 317-29

Caputo R.K. and A. Dolinsky (1998) Women's Choice to Pursue Self-Employment: The Role of Financial and Human Capital of Household Members. Journal of Small Business Management 36 (3), 8-17

Carr D. (1996) Two Paths to Self-Employment? Work and Occupations 23 (1), 26-53

Clark K. and S. Drinkwater (1998) Ethnicity and Self-Employment in Britain. Oxford Bulletin of Economics and Statistics 60 (3), 383-407

Cliff A.D. and J.K. Ord (1981) Spatial Processes: Models \& Applications. Pion: London

Cooper A.C., C.Y. Woo and W.C. Dunkelberg (1989) Entrepreneurship and the Initial Size of Firms. Journal of Business Venturing 4 (5), 317-32

Cressie N.A.C. (1993) Statistics for Spatial Data. Wiley: New York

Evans D.S. and L.S. Leighton (1989) Some Empirical Aspects of Entrepreneurship. The American Economic Review 79 (3), 519-35

Evans M.D.R. (1989) Immigrant Entrepreneurship: Effects of Ethnic Market Size and Isolated Labor Pool. American Sociological Review 54 (6), 950-62

Gimeno J., T.B. Folta, A.C. Cooper and C.Y. Woo (1997) Survival of the Fittest? Entrepreneurial Human Capital and the Persistence of Underperforming Firms. Administrative Science Quarterly 42 (4), $750-83$

Greenwood M.J. (1994) Potential Channels of Immigrant Influence on the Economy of the Receiving Country. Papers in Regional Science 73 (3), 211-40

Griffith D.A. (2003) Spatial Autocorrelation and Spatial Filtering: Gaining Understanding through Theory and Scientific Visualization. Springer: Berlin New York

Guerra G., R. Patuelli and R. Maggi (2010) Ethnic Concentration, Cultural Identity and Immigrant SelfEmployment in Switzerland. In P. Nijkamp, J. Poot and M. Sahin (eds), Migration Impact Analysis (tentative title). Edward Elgar (forthcoming): Cheltenham Northampton

Gulati R. (1998) Alliances and Networks. Strategic Management Journal 19 (4), 293-317

Gulati R. (1999) Network Location and Learning: The Influence of Network Resources and Firm Capabilities on Alliance Formation. Strategic Management Journal 20 (5), 397-420

Haining R. (1990) Spatial Data Analysis in the Social and Environmental Sciences. Cambridge University Press: Cambridge

Herfindahl O.C. (1950) Concentration In The Steel Industry. Unpublished Ph.D. Thesis, Columbia University, New York

Hirschman A.O. (1945) National Power and the Structure of Foreign Trade. University of California Press: Berkeley Los Angeles London

Kolvereid L. (1996) Prediction of Employment Status Choice Intentions. Entrepreneurship: Theory and Practice 21 (1), 47-57

Lazear Edward P. (1999) Culture and Language. Journal of Political Economy 107 (S6), S95-S126 
Le Gallo J. and C. Ertur (2003) Exploratory Spatial Data Analysis of the Distribution of Regional per Capita GDP in Europe, 1980-1995. Papers in Regional Science 82 (2), 175-201

LeSage J.P. and R.K. Pace (2009) Introduction to Spatial Econometrics. CRC Press: Boca Raton

Light I.H. (1972) Ethnic Enterprise in America: Business and Welfare among Chinese, Japanese, and Blacks. University of California Press: Berkeley

Light I.H. (1979) Disadvantaged Minorities in Self-Employment. International Journal of Comparative Sociology 20 (1), 31-45

Lindh T. and H. Ohlsson (1996) Self-Employment and Windfall Gains: Evidence from the Swedish Lottery. The Economic Journal 106 (439), 1515-26

Lomi A. (1995) The Population Ecology of Organizational Founding: Location Dependence and Unobserved Heterogeneity. Administrative Science Quarterly 40 (1), 111-44

Masurel E., P. Nijkamp, M. Tastan and G. Vindigni (2002) Motivations and Performance Conditions for Ethnic Entrepreneurship. Growth and Change 33 (2), 238-60

Meyer B.D. (1990) Why Are there so Few Black Entrepreneurs? (NBER Working Paper No. 3537). Cambridge: National Bureau of Economic Research

Minniti M. (2005) Entrepreneurship and Network Externalities. Journal of Economic Behavior \& Organization 57 (1), 1-27

Moro S., F. Chein and A.F. Machado (2003) Self-Employment in Brazil and its Determinants: A Spatial Analysis (Textos para Discussão Cedeplar-UFMG No. td204). Belo Horizonte: Cedeplar, Universidade Federal de Minas Gerais

Mueller P. (2006) Entrepreneurship in the Region: Breeding Ground for Nascent Entrepreneurs? Small Business Economics 27 (1), 41-58

Rees H. and A. Shah (1986) An Empirical Analysis of Self-Employment in the U.K. Journal of Applied Econometrics 1 (1), 95-108

Sanders J.M. and V. Nee (1996) Immigrant Self-Employment: The Family as Social Capital and the Value of Human Capital. American Sociological Review 61 (2), 231-49

Uzzi B. (1999) Embeddedness in the Making of Financial Capital: How Social Relations and Networks Benefit Firms Seeking Financing. American Sociological Review 64 (4), 481-505

Waller L.A. and C.A. Gotway (2004) Applied Spatial Statistics for Public Health Data. John Wiley \& Sons: Hoboken

Yuengert A.M. (1995) Testing Hypotheses of Immigrant Self-Employment. The Journal of Human Resources 30 (1), 194-204 


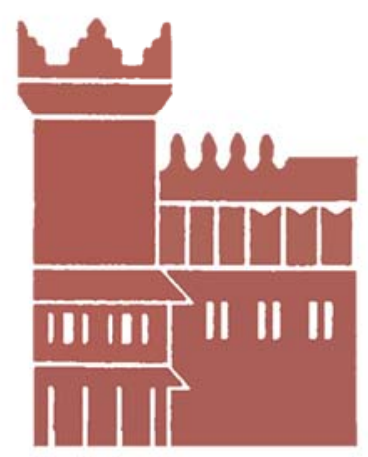

Alma Mater Studiorum - Università di Bologna DEPARTMENT OF ECONOMICS

Strada Maggiore 45

40125 Bologna - Italy

Tel. +39051 2092604

Fax +390512092664

http://www.dse.unibo.it 